2. ECN Category

(mark one)

Supplemental

Direct Revision

Change ECN

Temporan

Standby

Supersedure

Cancel/Noid
3. Originator's Name, Organization, MSIN, and Telephore No.

Edwin A.

[1] Harding/FDNW/B4-57/376-2398

6. Project Title/No./Work Order No.

Project $W-314$

II

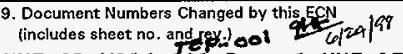

HNF-SD-W314-JOA Rev. 0, HNF-1733 Rev. $\not Z$ ! HNF-1902 Rev. $\not 1$ 12a. Modification Work

[] Yes (fill out Blk.

12b)

[X] No (NA Blks. 12b, 12c, 12d) \begin{tabular}{l|l} 
12b. Work Package & $12 \mathrm{c}$. Modification Work Complete
\end{tabular} No.

$N / A$
$N / A$

Design Authority/Cog. Engineer Signature \& Date

ECN

13a. Description of Change

13b. Design Baseline Document? [] Yes

1) Test \& Evaluation Plan For Project W-314, HNF-SD-W314- Rev. 1

Renamed Construction Acceptance Test (CAT) to Construction Test \& Inspection (CTI).

2) 241-AN-A Valve Pit Specific Test \& Evaluation Plan, HNF-1733 Rev. 2

Delete reference to Impact Wrench Assembly Factory Acceptance Test (FAT). Rename

Construction Acceptance Test (CAT) to Construction Test \& Inspection (CTI). Added

test review, approval, witness responsibilities.

3) 241-AN-B Valve Pit Specific Test \& Evaluation Plan, HNF-1902 Rev. 2

Rename Construction Acceptance Test (CAT) to Construction Test \& Inspection (CTI).

Added test review, approval, witness responsibilities.

14a. Justification (mark one)

Criteria Change $\quad[\mathrm{X}]$

As-Found

[X] Design Improvement

[] Facilitate Const

[] Environmental

[]

Const. Error/Omission

[] Facility Deactivation

$N / A$

14b. Justification Details

Corrected W-314 Test \& Evaluation Plan and 24l-AN-A Vaive Pit Specific Test \&

Evaluation Plan to reflect current Project status.

T5. Qistribution (include name, MSIN, and no. of copies]

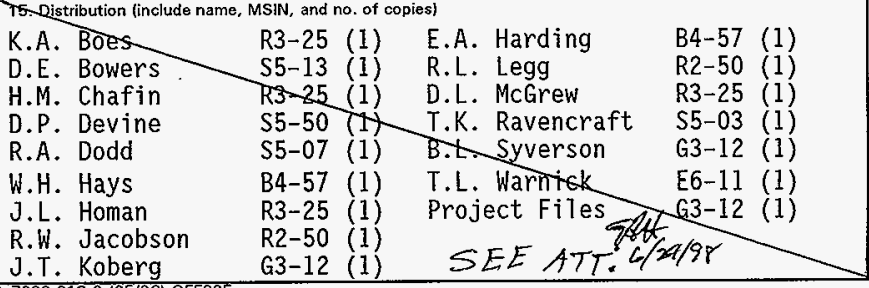

A-7900-013-2 (05/96) GEF095

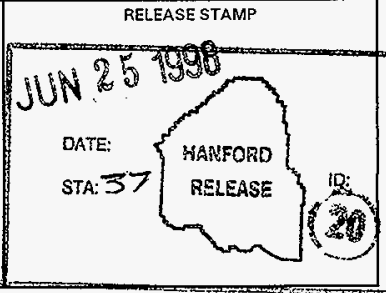




Page 2 of 2

1. ECN (use no, from pg. 1) 644838

\begin{tabular}{l|lccccc}
\hline $\begin{array}{l}\text { 16. Design } \\
\text { Verification } \\
\text { Required }\end{array}$ & \multicolumn{3}{|c}{17. Cost Impact } & & CONSTRUCTION \\
{[] Yes } & Additional & {[]} & $\$$ & Additional & {[]} & $\$$ \\
{$[X]$ No } & Savings & {[]} & $\$$ & Savings & {[]} & $\$$
\end{tabular}

18. Schedule Impact (days)

Imorovement

Delay
[]

19. Change Impact Review: Indicate the related documents (other than the engineering documents identified on Side 1)

that will be affected by the change described in Block 13. Enter the affected document number in Block 20.

SDD/DD
Functional Design Criteria
Operating Specification
Conceptual Design Report
Equipment Spec.
Const. Spec.
Procurement Spec.
Vendor Information
OM Manual
FSAR/SAR
Safety Equipment List
Radiation Work Permit
Environmental Impact Statement
Environmental Report
Environmental Permit

[] Seismic/Stress Analysis

$[1$

[]

[]

[]

[]

[]

[]

[]

[]

[]

[]

[]

[]

[]
Interface Control Drawing

Calibration Procedure

Installation Procedure

Maintenance Procedure

Engineering Procedure

Operating Instruction

Operating Procedure

Operational Safety Requirement

JEFD Drawing

Cell Arrangement Drawing

Essential Material Specification

Fac. Proc. Samp. Schedule

Inspection Plan

Inventory Adjustment Request
[]
[]
[]
[]
[]
[]
[]
[]
[]
[]
[]
[]
[]
[]
[]
[]

Tank Calibration Manual

Health Physics Procedure

Spares Multiple Unit Listing

Test Procedures/Specification

Component Index

ASME Coded Item

Human Factor Consideration

Computer Software

Electric Circuit Schedule

ICRS Procedure

Process Control Manual/Plan

Process Flow Chart

Purchase Requisition

Tickler File

N/A

20. Other Affected Documents: (NOTE: Documents listed below will not be revised by this ECN.) Signatures below indicate that the signing organization has been notified of other affected documents listed below.
Document Number/Revision
Document Number/Revision
Document Number Revision

\section{$\mathrm{N} / \mathrm{A}$}

21. Approvals

Signature

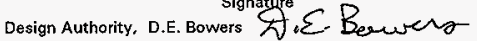

W-314 Startup Mgr., W.H. Hays C $D$ L $A$ ane

Project W-314 Proj. Mgr.. J. L. Homan

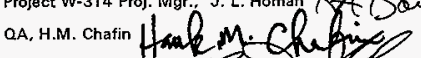

DSTF OPS.,

., R.A. Dodd

S.E. Mgmt.

Chief Test Director, R.L. Legg

Environ.

Safety

Other R, W. Jacobson
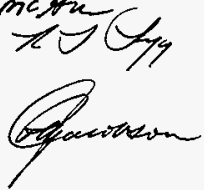

Date

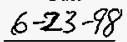

$6-23-98$

$6 / 23 / 98$

$6-23-98$

$6-23-98$

$\frac{6-23-98}{6-23}$

$6-23-78$

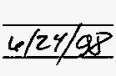

\section{DEPARTMENT OF ENERGY}

Signature or a Control Number that tracks the Approval Signature

\section{ADDITIONAL}

\section{Signature}

PE

QA, H.M. Chafin

Safety

Design

Environ.

other

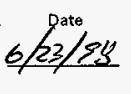

$6-23-98$

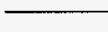




\section{TEST AND EVALUATION PLAN}

for Project $W-314$ Tank Farm Restoration and Safe Operations

\section{William H Hays}

Numatec Hanford Company, Richland, WA 99352

U.S. Department of Energy Contract DE-AC06-96RL13200

$\begin{array}{lll}\text { EDT/ECN: } & 644838 & \text { UC: } 2030 \\ \text { Org Code: } & 8 C 610 & \text { Charge Code: N314K } \\ \text { B\&R Code: } & \text { EW3130010 } & \text { Total Pages: } 42\end{array}$

Key Words: Test and Evaluation Plan, Tank Farm Restoration and Safe Operations, Project $\mathbf{W}-314$

Abstract: This Test \& Evaluation PIan (TEP) defines the objectives, roles, responsibilities, and overall strategy for conducting test \& evaluation activities for the $W-314$ Project.

TRADEMARK DISCLAIMER. Reference herein to any specific commercial product, process, or service by trade name, trademark, manufacturer, or otherwise, does not necessarily constitute or imply its endorsement, recommendation, or favoring by the United States Government or any agency thereof or its contractors or subcontractors.

Printed in the United States of America. To obtain copies of this document, contact: Document Control Services, P.O. Box 950, Mailstop H6-08, Richland WA 99352, Phone (509) 372-2420;

Fax (509) 376-4989.
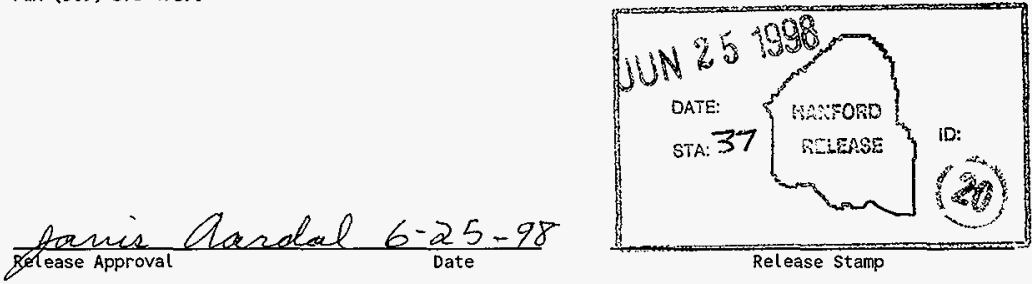
(2) ritle

Test and Evaluation $\mathrm{Pl}$ an

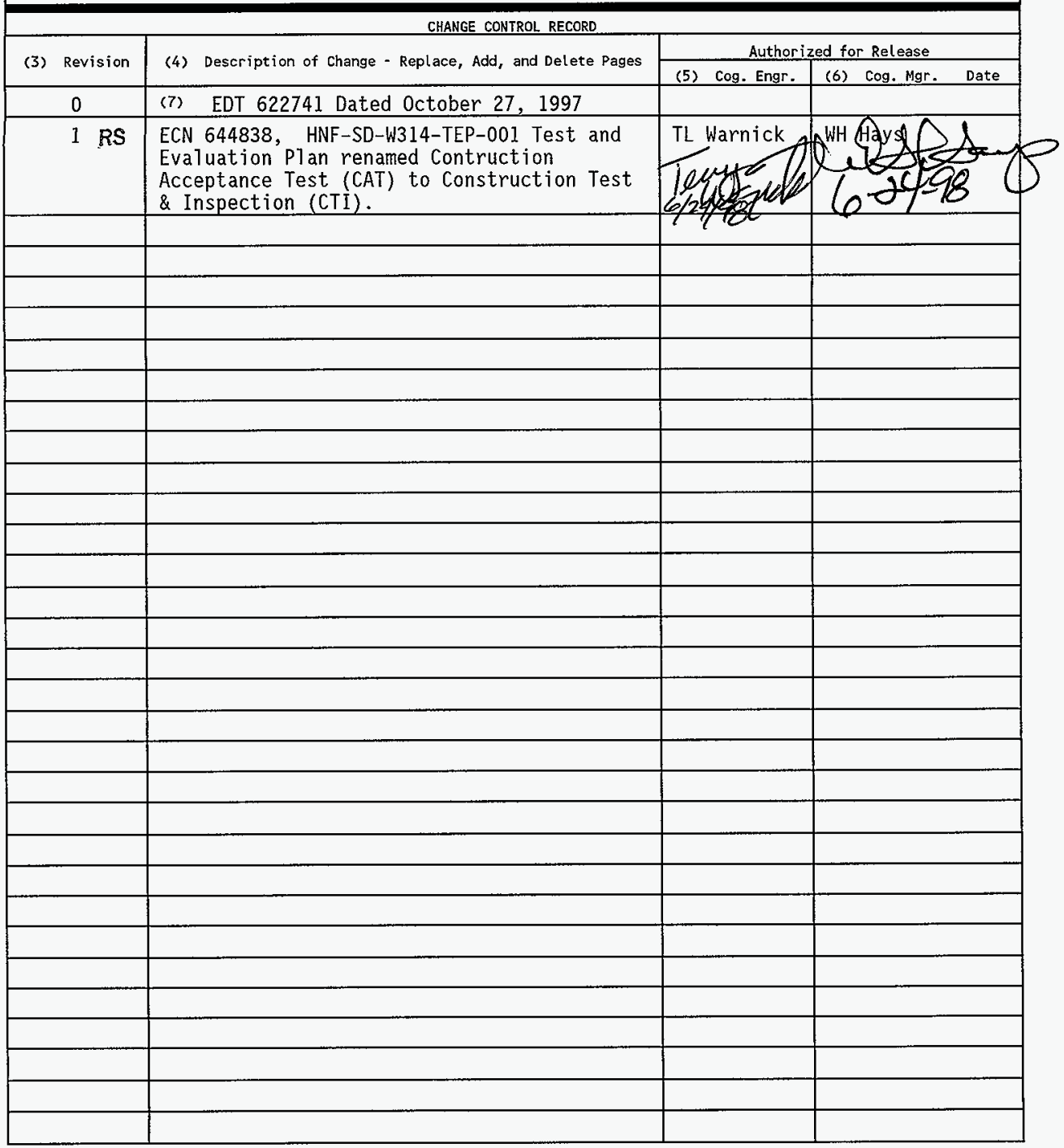


HNF-SD-W314-TEP-001, Rev. 1

\title{
TEST AND EVALUATION PLAN
}

$$
\text { for }
$$

PROJECT W-314

TANK FARM RESTORATION AND SAFE OPERATIONS

\author{
Prepared by \\ Fluor Daniel Northwest \\ June 22, 1998 \\ for
}

NUMATEC HANFORD CORPORATION 
TABLE OF CONTENTS

CHAPTER 1 INTRODUCTION, PURPOSE, AND SCOPE . . . . . . . . . . . . 1

1.1 INTRODUCTION . . . . . . . . . . . . . . . . . . . 1

1.2 PURPOSE ........................... . . . . . . . . . . . . . . . . . . . . . . . . . . . .

1.3 SCOPE .......................... 2

CHAPTER 2 GOALS AND OBJECTIVES . . . . . . . . . . . . . . . . 3

2.1 GOALS ....................... 3

2.2 OBJECTIVES ...................... 3

2.3 T\&E DESIGN PHASE ........................ 3

2.4 T\&E CONSTRUCTION PHASE .................... 4

2.5 T\&E TURN-0VER PHASE ........................ 6

2.6 T\&E OPERATIONS AND MAINTENANCE PHASE .............. 8

CHAPTER 3 ORGANIZATION AND RESPONSIBILITIES . . . . . . . . . . . . 10

3.1 DEPARTMENT OF ENERGY (DOE-RL) .................. 10

3.2 FLUOR DANIEL HANFORD ........................ 10

3.3 PROJECT MANAGEMENT (NHC) . . . . . . . . . . . . . . . 10

3.3.1 PROJECT MANAGEMENT AND ENGINEERING . . . . . . . . . . 10

3.3.2 TFRSO STARTUP GROUP .................. 11

3.4 JOINT TEST REVIEW GROUP (LMHC) . . . . . . . . . . . . . . 12

3.5 TEST SUPPORT GROUP (FDNW) .................. 13

3.6 TANK FARM OPERATIONS (LMHC) ................... . 13

3.6.1 CHIEF TEST DIRECTOR . . . . . . . . . . . . 14

3.7 MAINTENANCE GROUP (LMHC) . . . . . . . . . . . . . . . . . 14

3.8 DESIGN AGENT (FDNW) . . . . . . . . . . . . . . . . 15

3.9 CONSTRUCTION (FDNW) . . . . . . . . . . . . . . . . . . 15

3.10 MATRIXED ORGANIZATIONS . . . . . . . . . . . . . . . . 16

3.11 QUALIFICATION AND TRAINING . . . . . . . . . . . . . . 17

CHAPTER 4 PROJECT W-314 STRATEGY AND APPROACH . . . . . . . . . . . . . . 20

4.1 T\&E ADMINISTRATIVE ACTIVITIES . . . . . . . . . . . . . . 20

4.2 T\&E WORK CONTROLS . . . . . . . . . . . . . . . . . 20

4.3 PROJECT MANAGEMENT ENGINEERING . . . . . . . . . . . . . . . 21

4.4 FILING AND RECORDS MANAGEMENT . . . . . . . . . . . . . . 22

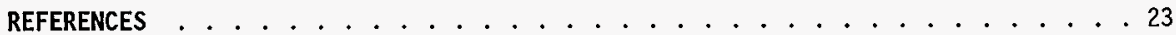

GLOSSARY . . . . . . . . . . . . . . . . . . . . . . . 25 
TABLE OF CONTENTS (CONT.)

\section{APPENDICES}

APPENDIX A T\&E ADMINISTRATIVE PROCEDURES CHECKLIST . . . . . . . . . . 26

APPENDIX B TEST AND EVALUATION LOGIC DIAGRAM AND OVERVIEW DEFINITION DOCUMENT . 28

\section{LIST OF TABLES AND FIGURES}

2-1 W-314 TESTING AND EVALUATION ACTIVITIES . . . . . . . . . . . . 9

3-1 RESPONSIBILITY ASSIGNMENT MATRIX . . . . . . . . . . . . 18

A-1 T\&E AdMINISTRATIVE PROCEDURE MATRIX FOR TESTING . . . . . . . . . 27

B-1 OVERVIEW DEFINITION DOCUMENT . . . . . . . . . . . . . 29

B-2 TESTING AND EVALUATION LOGIC DIAGRAM .............. 30

B-3 V\&V LOGIC DIAGRAM FOR AN TANK FARM . . . . . . . . . . . 31

B-4 V\&V LOGIC DIAGRAM FOR 200E/200W . . . . . . . . . . . . 32

B-5 V\&V LOGIC DIAGRAM FOR AW TANK FARM .............. . . 33

B-6 V\&V LOGIC DIAGRAM FOR AY TANK FARM . . . . . . . . . . . . 34

B-7 V\&V LOGIC DIAGRAM FOR AZ TANK FARM ............. . . 35

B-8 V\&V LOGIC DIAGRAM FOR MASTER PUMP SHUTDOWN SYSTEM . . . . . . 36 


\section{ABBREVIATIONS AND ACRONYMS}

ABU Acceptance for Beneficial Use

$A-E \quad$ Architect-Engineer

AI Acceptance Inspection

ATP Acceptance Test Procedure

ATR Acceptance Test Report

BI0 Basis for Interim Operation

CTI Construction Tests \& Inspections

CGA Calibration and Grooming Activities

$C M \quad$ Construction Management

COTS Commercial off The Shelf

DOE U.S. Department of Energy

ECN Engineering Change Notice

FTI Factory Tests \& Inspections

FDH Fluor Daniel Hanford

FDNW Fluor Daniel Northwest

HNF Hanford

HVAC Heating, Ventilation, and Air Conditioning

JCS Job Control System

LMHC Lockheed Martin Hanford Company

M\&TE Measurement and Test Equipment

MTS Master Tracking System

NHC Numatec Hanford Corporation

O\&M Operations and Maintenance

OTP Operational Test Procedure

OTR Operational Test Report

P\&ID Piping and Instrumentation Diagram

PCP Process Control Package

PDS Project Development Specifications

PHMC Project Hanford Management Contractor

POTP Pre-Operational Test Procedure

QA Quality Assurance

RL U.S. Department of Energy, Richland Operations Office

SSC Structures, Systems and Components

STEP Specific Test \& Evaluation PTan

SU Startup

T\&E Test \& Evaluation

TEP Test \& Evaluation Plan

TFRSO Tank Farm Restoration and Safe Operations

TIM Training Implementation Matrix

TWRS Tank Waste Remediation System

WBS Work Breakdown Structure 


\section{CHAPTER 1}

\section{INTRODUCTION, PURPOSE, AND SCOPE}

\subsection{INTRODUCTION}

The "Tank Farm Restoration and Safe Operations" (TFRSO), Project $W-314$ will restore and/or upgrade existing Hanford Tank Farm facilities and systems to ensure that the Tank Farm infrastructure will be able to support near term TWRS Privatization ${ }^{*} s$ waste feed delivery and disposal system and continue safe management of tank waste. The capital improvements provided by this project will increase the margin of safety for Tank Farms operations, and will aid in aligning affected Tank Farm systems with compliance requirements from applicable state, Federal, and local regulations. Secondary benefits will be realized subsequent to project completion in the form of reduced equipment down-time, reduced health and safety risks to workers, reduced operating and maintenance costs, and minimization of radioactive and/or hazardous material releases to the environment.

The original regulatory (e.g., Executive Orders, WACs, CFRs, permit requirements, required engineering standards, etc.) And institutional (e.g., DOE Orders, Hanford procedures, etc.) Requirements for Project $W-314$ were extracted from the TWRS S/RIDS during the development of the Functions and Requirements (F\&Rs). The entire family of requirements were then validated for TWRS and Project $W-314$. This information was contained in the RDD-100 database and used to establish the original CDR.

The Project Hanford Management Contract (PHMC) team recognizes that safety, quality, and cost effectiveness in the Test and Evaluation (T\&E) program is achieved through a planned systematic approach to T\&E activities. It is to this end that the Test and Evaluation Plan (TEP) is created.

The TEP for the TFRSO Project, was developed based on the guidance in HNF-IP-0842, and the Good Practice Guide GPG-FM-005, "Test and Evaluation," which is derived from DOE Order 430.1, "Life Cycle Asset Management." It describes the Test and Evaluation program for the TFRSO project starting with the definitive design phase and ending with operational testing and turn-over of the upgraded systems to Tank Farm Operations. The TEP wi11 be updated as required to reflect the appropriate test acceptance and startup requirements to support design, construction, turnover and initial operations. This TEP embodies the following purpose and scope of application for the TFRSO Project.

\subsection{PURPOSE}

The purpose of the TFRSO TEP is to identify and plan the T\&E activities and strategies required to confirm that the Systems, Structures, and Components (SSCs) provided by the TFRSO will satisfy their functional requirements as outlined in the Project Development Specification (PDS). The TEP will also describe the T\&E program to be undertaken during the various project phases. This TEP establishes a sequence of test, support, and evaluation activities deemed necessary to provide confidence that ail required T\&E activities will be accomplished successfully to support a smooth and timely turnover of completed TFRSO upgrades to the Tank Farm Operations customer. The sequence of T\&E activities can be found in the logic diagrams and Overview Definition Document OF Appendix B. The Overview Definition Document and Logic Diagrams provide a visible indication of the type of testing and the order of testing respectively. In addition to providing a roadmap for T\&E and related support activities, the TEP outlines organizational responsibilities for managing 
and performing the testing and evaluation activities. This includes an overview of each participating organization's management responsibilities, interfaces, 1 ines of authority, accountability, qualification, and independent verifications.

\subsection{SCOPE}

The TFRSO Test and Evaluation PIan encompasses the overall set of T\&E activities that are planned for Project $W-314$. A graded approach shall be used to determine what level of T\&E effort will be employed on the various elements of the TFRSO Project. This graded approach shall ensure that T\&E principles and practices are incorporated commensurate with factors such as complexity, visibility, and risk to ensure successful project completion. Since the project encompasses many systems and facilities spread over a long period of time, separate lower tier Specific Test and Evaluation Plans (STEPS) will be developed for turnover segments within the project. Each of these separate segments will be aligned with the Acceptance for Beneficial Use (ABU) packages.

The Acceptance for Beneficial Use process will identify and track all relevant documentation for project turnover. The STEPs will identify specific testing activities and at what phase of the project these activities should take place.

Testing and Evaluation activities may include Factory Tests \& Inspections (FTIs), Construction Tests \& Inspections (CTIs), Acceptance Tests Procedures (ATPS), Pre-operational Tests Procedures (POTPS), Operational Tests Procedures (OTPs), Calibration, Grooming, and Alignment (CGA) activities, In-Process Testing performed during the construction and procurement phases, and any other such tests or evaluations required to verify that the end product(s) meet the requirements identified in the approved design baseline documents. Descriptions of the various T\&E activities are discussed in the corresponding T\&E phase found in chapter 2. 


\section{CHAPTER 2}

\section{GOALS AND OBJECTIVES}

The following sections identify the goals and objectives that the TEP will attain. Additionally, the types of testing conducted during various phases (i.e., design, turnover...etc) of the Project will be described in greater detajl. Also, Table 2-1 (found on page 9 ) provides a quick reference to the respective T\&E activities associated with each phase and their subsequent objectives.

\subsection{GOALS}

The goal of this TEP is to ensure the integrity and operability of the upgraded SSCS are in accordance with their PDS documents, and to demonstrate the readiness of operations and management to safely and effectively operate these upgraded SSCS.

\subsection{OBJECTIVES}

The overall objectives of the TFRSO T\&E program are to demonstrate the TFRSO upgraded SSCs are (a) compliant with the requirements of the approved PDS; (b) constructed in accordance with approved design drawings and procurement/construction specifications; c) installed properly and appropriately integrated into the existing system; and (d) will operate safely upon turn-over to the customer. This document will provide the integration of all testing activities to ensure the above objectives are met. This integration can be seen by reviewing the Logic Diagrams in Appendix B. Complete and successful SSC testing will be accomplished by conducting the tests designated in the corresponding STEP. The STEP defines the SSC(s) that will be tested, the test boundaries, the test acceptance criteria, test requirements, and type of tests (i.e., FTIs, CTIs, ATPs...etc.) that are required.

Table 2-1 (found on page 9) provides the TFRSO T\&E strategy and approach during the project. Note that Table 2-1 is structured to show that the objectives of a given T\&E activity must be fulfilled before progressing on to the activity of the next phase. A brief description of the T\&E activities, as depicted in Table 2-1, along with a brief description of the project strategy/approach to accomplish the T\&E activity, are summarized in the following sections.

\subsection{T\&E DESIGN PHASE}

Testing and evaluation activities during the design phase are focused on demonstrating that the SSCS, as designed, meet the requirements specified in the PDS. This is referred to as "design verification" in Table 2-1 and other sections of this document. The overall objective of design verification is to determine if the design of the SSC(s) meet the requirements of the PDS. The TFRSO design, as documented in drawings and construction/procurement specifications, is evaluated against the requirements of the applicable PDS by the methods described in Section 4 of the PDS. The four possible methods of design verification, or "Quality

conformance Inspections" as it is referred to in the PDS, are as follows:

- ANALYSIS - an element of inspection, taking the form of the processing of accumulated results and conclusions, intended to provide proof that verification of a requirement(s) has been accomplished. The anaiytical results may be comprised of a compilation of interpretation of existing information or derived from lower level examinations, tests, demonstrations, or analysis. 
- DEMONSTRATION - an element of inspection that is limited to readily observable functional operation to determine compliance with requirements. This element of inspection does not require the use of special equipment or sophisticated instrumentation. It should be noted that most of these activities will occur during the T\&E construction phase.

- EXAMINATION - an element of inspection consisting of investigation, without the use of special laboratory appliances or procedures, to determine compliance with requirements. It should be noted that most of these activities. will occur during the T\&E construction phase.

- TEST - an element of inspection that employs technical means including (but not limited to) the evaluation of functional characteristics by use of special equipment or instrumentation, simulation techniques, and the application of established principles and procedures to determine compliance with requirements. The analysis of data derived from test is an integral part of this inspection. It should be noted that most of these activities will occur during the T\&E construction phase.

It should be noted, that any one, or combination thereof, of the above methods may be specified in the PDS as applicable verification methods.

The design approach for TFRSO SSCs is to incorporate Commercial off The Shelf (COTS) products as much as possible. Therefore, one of the objectives of design verification witl be to confirm that the $\operatorname{SSC}(s)$ meet the requirements of the corresponding PDS(s) through the use of analysis, demonstration, and/or examination. No special design verification tests have been identified at this time. This objective will be met by reviewing vendor data sheets and catalog cut sheets, evaluation of similar hardware under similar usages, review of the design drawings and construction/procurement specifications by the appropriate engineers, and any needed analyses utilizing such information will be performed to accomplish design verifications.

other T\&E activitjes conducted during the design phase include planning of the T\&E program for the TFRSO Project. Planning includes development of the TFRSO TEP and the Specific Test \& Evaluation Plans identified in Appendix B of this TEP. The purpose and scope of the TFRSO TEP is described in Chapter 1 of this TEP, however, the purpose and scope of each specific STEP will be described in each STEP. The needed procedures and plans will be specified by the STEPs so that specific tests and/or evaluations to be conducted can be carried-out in an orderly and timely manner. The overall objectives to effective T\&E planning are to understand, integrate, schedule, and resource load T\&E activities and to communicate, at various levels, the T\&E activities to be performed on TFRSO SSCS.

\subsection{T\&E CONSTRUCTION PHASE}

Construction testing activities are comprised of various tests and inspections that demonstrate compliance with procurement and construction specifications.

Satisfactory completion of these tests are required to allow transition into pre-testing activities (for POTPS and OTPS), which are comprised of Calibration, Grooming, and Alignment (CGA) activities followed by Pre-operational Tests and Operational Testing. Thus, test and evaluation activities, conducted during the construction phase of the TFRSO project, are focused on demonstrating the following: 
- the delivered SSCs have been manufactured to the requirements found on the approved drawings and specifications and

- the SSCs have been properly constructed and/or installed.

To accomplish the above, there are several different types of construction T\&E activities that could occur. Factory Tests \& Inspections (FTIs), mock-up tests, Acceptance Test Procedures (ATPs), and other Construction Tests \& Inspections (CTIs) (e.g., hydro tests, pneumatic tests, megger tests etc...) will be performed to demonstrate that the TFRSO SSCS will perform per the requirements of the approved design media. Every effort will be made to ensure the SSCs have been properly completed, installed, groomed, and/or inspected for completeness prior to initiation of construction and acceptance testing.

The overall objective of the FTIs is to determine that the manufactured SSC is adequate and ready for instaliation. The FTI is used to satisfy design verifications by demonstration, examination, and/or testing. For the FTI, the manufactured SSC is ultimately evaluated against the requirements of the app Ticable drawings and/or procurement specification. For specific FTIs conducted, the acceptance criteria shall be based on the drawing and/or procurement specification requirements. Additionally, FTIs may be generated and contain hold points that require a witness signature to "buy off" the SSC; therefore, confirming that all acceptance requirements are met. A factory acceptance test report will be generated when al1 test exceptions have been cleared and the test has been successfully completed.

The TFRSO impiementation of FTIs vary depending on the risk factors and complexity of the SSC. Non-complex SSCs may be evaluated via a review of the vendor's catalog cut sheets and data sheets. An engineering analysis may be required to further assure and document the adequacy of the equipment or SSC being evaluated. This will provide insight into the adequacy of the vendor supplied COTS equipment in meeting the procurement specification. In some instances, vendor qualification is performed by an. evaluation of the vendor's manufacturing processes and quality assurance program. On complex SSCs, more stringent requirements may be imposed to assure compliance with the drawings and/or specifications. This may include that the buyer be present at the vendor's facjlity to witness testing and/or the manufacturing process. SSC complexity will be determined by reviewing the procurement and construction specifications and other design documents.

A mockup test of the Pit Leak Detectors will be performed prior to installation to ensure that the performance requirements, found in the Project Development Specifications, are met. Note that this mockup test will be performed only once to verify design.

CTIs will be identified in Construction Work Packages (CWPs) based on requirements found on the drawings and construction specifications; whereas, ATPs are separate "stand alone" documents which obtain their requirements from the applicable PDS and vendor data. The CTI is used to satisfy design verification requirements via demonstration, examination, and testing. ATPS and CTIs will ensure that the SSCS are fabricated and/or installed properiy to provide safe and reliable operation.

Detailed CTI procedures may be required for conducting non-routine functional checks and/or inspections during SSC installations. Detailed ATPS will be required after the CTI functional checks and/or inspections are completed and, will validate overall SSC installation as a whole. For CTIS, the acceptance criteria shall be specified in either the CTI and/or on approved drawings and specifications. For ATPS, the acceptance criteria will be specified in the ATP. 
CTI and ATP implementation will also vary depending on the complexity and risk factor involved with the applicable SSC. CTIs may require Quality Assurance (QA) to witness and approve the installation. It will be delineated, in each specific STEP document, who is required to witness and/or approve the respective CTI or ATP. All CTIs and ATPS shali be documented to record results and any follow-up activities necessary to accept the SSC for turnover to the customer. CTI's are documented in the applicable CWP. An Acceptance Test Report (ATR), for each ATP, will be generated when all test exceptions have been cleared and the test has been successfully completed.

The Design Agent is required to prepare test requirements and acceptance criteria for FTIs and CTI for inclusion in procurement and construction specifications. Detailed test plans and/or ATPs may be prepared by the design agent, construction contractors, or vendor/suppliers in accordance with requirements of procurement and construction specifications and vendor data. These detailed plans and/or ATPS will be reviewed and approved by the design agent, and other PHMC participants as requested by the Project Manager. Selected ATPS, when defined by HNF-IP-0842 Vol. II sec. 4.1.3, may undergo a thorough review by the Joint Test Review Group. The FTIs and CTIs will be performed by the responsible organization (i.e., construction contractor or vendor/supplier). These tests may be witnessed by Fluor Daniel Northwest, as required, to ensure test requirements are met. The test data will be included in the Acceptance for Beneficial Use (ABU) turnover packages. Satisfactory completion of construction and transfer of the completed SSC to the user/sponsor organization will be documented using the Acceptance of Completed Work (ACW) form.

Although TFRSO Startup is not responsible for construction testing and inspection, TFRSO Startup will be present in an oversight role that may take administrative control of equjpment and portions of systems before completion of construction acceptance testing in order to begin acceptance testing procedure or pre-operational testing as soon as possible to meet project milestones. This will assure a smooth transition into the Startup phase of the project. Safe work boundaries, utilizing TWRS Lock and Tag system, will be established as work progresses and at each phase of the Project.

\subsection{T\&E TURN-OVER PHASE}

The test and evaluation activities conducted during the turn-over phase of the TFRSO Project focus on demonstrating the following:

- the installed SSCs function properly within the system as a whole and

- the system, with SSCs installed, will operate under normal operating conditions and/or anticipated off-normal conditions.

The primary T\&E activities that accomplish the previous objectives are referred to as Pre-Operational Tests Procedures (P0TPs) and Operational Test Procedures (0TPS).

The overall objective of the POTPs is to determine if the installed SSCs function as intended when integrated into the system as a whole. Also, ensure that the SSCS operate safely and reliably. For POTPs, the installed SSCS are ultimately evaluated against the requirements of the applicable PDS and TWRS Basis for Interim Operation (BIO) document. Pre-Operational testing may be performed on individual segments of SSCs to demonstrate that plant systems or subsystems perform as designed. The design agent may be requested to prepare test specifications for pre-operational tests which contain test requirements and acceptance criteria including, requirements and instructions from the vendors for specific items of equipment. The 
Startup organization will ensure that test procedures are prepared from these specifications which provide instructions for conduct of the tests. The procedures will be reviewed by the owner's Joint Test Review Group (JTRG) prior to conducting the test. If a POTP has been generated but the testing of the corresponding SSC won't be performed for an extended period of time (e.g., year or more), then the POTP must be reviewed again, prior to performance of the test, to ensure that it is still applicable. A pre-operational test report will be generated when all test exceptions have been cleared and the test has been successfully completed.

Required OTPs will be planned, scheduled, and conducted, on the installed SSCs, after completion and acceptance of all other test results. These detailed procedures shall determine if the installed SSCS function as intended when integrated into the system as a whole. All systems are brought on-line and operated under anticipated standard operating conditions and off-normal conditions; thus, verifying that the SSCS operate safely and reliably. Included in the OTP will be acceptance criteria to delineate pass/fail requirements. Operational testing is performed with actual plant equipment, operating procedures, and personnel. If an OTP has been generated but the testing of the corresponding SSC won't be performed for an extended period of time (e.g., a year or more), then the OTP must be reviewed again, prior to performance of the test, to ensure that it is still applicable. A Operational Test Report (OTR) will be generated when all test exceptions have been cleared and the test has been successfully completed.

Since this is an integrated system level test, the acceptance criteria shall be based on the requirements specified in the approved design media, operational procedures, existing operational requirements, and the BIO.

The process by which this information will be turned over is called the ABU process.

The objective of the TFRSO Project T\&E activities, conducted during the turn-over phase, is to plan and execute the tests with coordination from the projects, operations, and maintenance organizations. This coordination will ensure a smooth transition during the turn-over process. Included in the turnover to the end user wi11 be the necessary operating and maintenance procedures, training on the system, and initial spare parts listings necessary for system maintenance.

The test and evaluation activities conducted during the turn-over phase of the TFRSO Project focus on delivering the following:

- Al1 documents needed to operate and maintain the SCC provide by the TFRSO project. This includes any operation personnel training, procedure updates, spare parts availability, and final operating test reports.

- Any necessary readiness review documents or assessments procedure that determine whether the modified SSC operate under or change current Operating Safety Requirements and the current TWRS BIO document.

The process in which those items listed above are turned over to the end user (Tank Farm Operation) is called the Acceptance of Structures, Systems, and Components for Beneficial Use Process or ABU. The $A B U$ will identify and track all relevant documentation necessary to complete project turnover. The $A B U$ will also identify the roles, responsibilities, of those participating in each turnover activity. The ABU will support project planning by providing a written agreement with the end user of what are the project deliverables for project closure. The end user will 
identify those documents and training material up-front, so that the project can budget and schedule the work appropriately.

For TFRSO project closure, each design package will have its own ABU documentation. This ABU documentation will constitute closeout of that particular design package and signify "readiness" for end user ownership. The ABU will support a smooth transition of ownership of the modified SSC from the project to the end user. The Official Acceptance of Construction (OAC) will document the transfer of all the ABUS and design packages for each construction phase from construction to operations.

The TFRSO project ABUs will be written and followed in accordance with HNF-IP-0842, Vol. IV, section 3.12 .

\subsection{T\&E OPERATIONS AND MAINTENANCE PHASE}

This phase of a project as described in DOE order 430.1 is supported in the startup phase of the TFRSO Project. The project supplies the necessary tools to the Operation Manager to meet these requirements. These tools include as built design media, operational and maintenance procedures, and initial set of spare parts, and a spare parts 1ist.

Test and evaluation activities during the operations and maintenance (0\&M) phase focus on demonstrating that the SSCs are operational and perform at levels consistent with the design and operational requirements. This objective will be met by ensuring T\&E activities are conducted in accordance with detajled 0\&M test procedures. 
HNF-SD-W314-TEP-001, Rev . 1

Table 2-1. W-314 TESTING AND EVALUATION ACTIVITIES, OBJECTIVE AND APPROACH

\begin{tabular}{|c|c|c|c|c|}
\hline \multirow{2}{*}{$\begin{array}{l}\text { DOE } 430.1 \\
\text { LIFE CXCLE PHASE }\end{array}$} & \multicolumn{3}{|c|}{ EXECUTION PHASE } & \multirow{2}{*}{$\begin{array}{c}\text { OPERATTONS } \\
\text { AND } \\
\text { MAINENANCE }\end{array}$} \\
\hline & DESIGN & CONSTRUCTION & TURNOVER & \\
\hline $\begin{array}{l}\text { TEST \& EVALUATION } \\
\text { ACTIVITY }\end{array}$ & 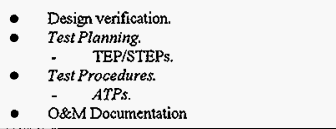 & $\begin{array}{l}\text { - Acceptance Testing } \\
\text { - } \quad \text { Factory Acceptance Tests (FTIs). } \\
\text { - Mockup Test } \\
\text { - } \quad \text { Gonstruction Tests \& Inspections (CTIs) } \\
\text { - } \quad \text { Acceptang and Alignment } \\
\text { Test Procedure (ATPs). }\end{array}$ & $\begin{array}{l}\text { - Calibration and Grooming Activities (CGA), } \\
\text { Equipment \& Tag Lists, As-Builts Dws, and other } \\
\text { necessary SSC aligrment items } \\
\text { - } \quad \text { Pre-operational Testing (Startup). } \\
\text { - } \quad \text { Operational testing (Startup supported). } \\
\text { - ABU Documentation checklist (Startup) }\end{array}$ & $\begin{array}{l}\text { - Startup (T\&E) activities completed, SSC } \\
\text { tutmover to Operation. }\end{array}$ \\
\hline ORIECTIVE & $\begin{array}{l}\text { - Determine if SSCs are ready for } \\
\text { construction. } \\
-\quad \text { Verify design as documented in } \\
\text { drawings, construction and } \\
\text { procurement specification meet the } \\
\text { requirements of the PDSs. } \\
\text { Finalize Test Planning. } \\
\text { - Test Plans. } \\
\text { - Schedule and Resources. }\end{array}$ & 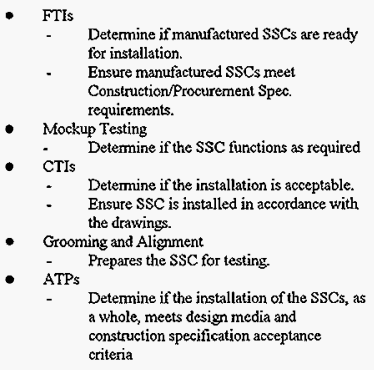 & $\begin{array}{l}\text { - Determine if installed SSCs function properly. } \\
\text { - Check against PDS. } \\
\text { Determine if the entire integrated system perfoms } \\
\text { as required. } \\
-\quad \text { Check SSC against PDS. } \\
\text { - Check system against Design Media, Const. } \\
\text { Ppec, System Spec. } \\
\text { Provide documentation and training on SSC. } \\
\text { - Provide operation and maintenance the tools } \\
\text { - } \quad \text { operate and maintain SSC. } \\
\text { intended furctions to the required } \\
\text { performance levels. }\end{array}$ & $\begin{array}{l}\text { - Operation \& Maintenance provided with the } \\
\text { training and support tools needed to } \\
\text { maintain and operate } S S C \text { as intended. } \\
\text { NOTE - Completed during tumover phase of } \\
\text { Project }\end{array}$ \\
\hline $\begin{array}{l}\text { PROJECT W-314 } \\
\text { STRATEGY/APPROACH }\end{array}$ & $\begin{array}{l}\text { - Use COTS hardware. } \\
\text { Design verification will be done by } \\
\text { Analysis, Exam, and'or } \\
\text { Demonstration. NO TEST. } \\
\text { Vendor Data Sheots. } \\
\text {-Write TEP. } \\
\text { Conmunicate T\&E } \\
\text { Approach/Sirategies. } \\
\text { Integrate T\&E activities and } \\
\text { resources across separate design } \\
\text { packages in the TEP. } \\
\text { Define and delegate responsibilities. } \\
\text { - Write Test Plans/Procedures. }\end{array}$ & $\begin{array}{cl}\text { - FTIs } & \\
- & \text { Review vendor's QA program. } \\
- & \text { Examine vendor's process, product } \\
& \text { assembly procedures. } \\
-\quad & \text { Review and witness vendor's testing } \\
\text { CTIs } & \\
- & \text { Review constructors QA program. } \\
- & \text { Surveillance of construction. } \\
- & \text { Review and witness construction testing. }\end{array}$ & $\begin{array}{l}\text { - Conduct tests to ensure successful completion of } \\
\text { - Me above objectives. } \\
\text { - Maintenance testing procedure approved and ready } \\
\text { - Mor use } \\
\text { Maintenance system updated to schedule testing at } \\
\text { appropriate frequency (PMs). } \\
\text { Spare parts availability, equipment properly } \\
\text { maintained and protected during storage \& } \\
\text { installation. } \\
\text { ABU Documentation checllist } \\
\text { - Ensure the above documentation is complete, } \\
\text { including any readiness assessments needed } \\
\text { for tumover. }\end{array}$ & - SSC tumover, project complete. \\
\hline
\end{tabular}




\section{CHAPTER 3}

\section{ORGANIZATION AND RESPONSIBILITIES}

The following sections identify the organizations and describe, in greater detail, their roles and responsibilities during their direct participation in the T\&E process for the TFRSO project. In addition, Table 3-1 (page 18), communicates each specific responsibility and testing alignment, respectively.

\subsection{DEPARTMENT OF ENERGY (DOE-RL)}

The TFRSO project, $W-314$, will be managed by an integrated management team approach. The Department of Energy, Richland Operations Office, is responsible for the project's top-level functional requirements. The PHMC has been delegated the responsibility to manage and implement the day-to-day project activities, including all T\&E activities.

\subsection{FLUOR DANIEL HANFORD}

Fluor Daniel Hanford is the "Integrating Contractor". Their role is to establish and manage the Hanford site-wide configuration management program as an umbrella for alT Fluor Daniel Hanford subcontracts. FDH is responsible for administrative procedures (e.g., PHMC guidance for performing inspections and testing) that apply to the Project.

\subsection{W-314 TFRSO PROJECT MANAGEMENT (NHC)}

\subsubsection{PROJECT MANAGEMENT AND ENGINEERING}

Project Management and Engineering, which includes the Project Manager, Lead Project Engineer, Quality Assurance, Safety and Health, and Environmental Compliance, is responsible for planning, organizing, directing, and controlling project resources for the cycle of the project to achieve a goal of completing the project on schedule and within budget. Included is responsibility to act as an interface between the Design Authority and the Design Agent. Additionally, the Project Manager will perform within guidelines, policies, procedures, rules, and directives of Tank Farms (LMHC), the parent organization (FDH), and DOE.

Quality Assurance ensures that all T\&E activities will be performed in accordance with the requirements of the Tank Farm Restoration and Safe Operations Quality Assurance Program Plan, HNF-SD-W314-QAPP-001.

Safety and Health responsibility, for T\&E activities, shall be to manage their activities in accordance with the TFRSO Project Execution Plan, HNF-SD-W314-PMP-001, the Project System Safety Program PIan, HNF-SD-W314-SSPP-001, and a11 other applicable Federal, DOE, and State safety codes and requirements. The TFRSO Startup Group shall also be responsible for including elements of the project safety basis documentation into operator training, operations and maintenance procedures, and test procedures.

Environmental Compliance responsibility, for T\&E activities, shall be to manage their activities in accordance with the TFRSO Project Execution Plan, 
HNF-SD-W314-PMP-001, along with all applicable regulatory permits that apply to the TFRSO Project.

Included with the responsibilities mentioned in the paragraphs above, are the following examples:

- Witness factory tests \& inspections, construction tests \& inspections, acceptance testing, pre-operational testing, and operational testing.

- Review Requirement Verification Reports, procurement specifications, construction specifications, and ATPs.

- Approve Requirement Verification Reports, procurement specifications, construction specifications, ATPs and construction completion report (4Cs).

- Review and approve Factory Test \& Inspection reports, construction acceptance test reports, ATRs, POTP reports, and OTRs.

- Provide a point of contact for startup activitjes and coordinate with TFRSO Startup Group.

- Provide oversight of work performed during testing and evaluation activities.

- Provide and/or concur with all test results or reports.

- Participate in Joint Test Review Group activities.

\subsubsection{TFRSO STARTUP GROUP}

The TFRSO Startup Group, which includes the Lead Test Engineer, is part of the Project Team and a highly matrixed organization. This includes FDNW contracted support assisting NHC in the startup role by directing startup and turnover activities. In its integration role, Startup will provide startup related technical direction, cost and scheduling management, control, integration assistance, appiied technology, turnover, and safety/regulatory compliance support. The Startup organization's management of the T\&E activities is developed in greater depth in chapter 4. Startup will develop, coordinate, and implement TFRSO Project's Testing \& Evaluation Program. This includes identification, development, and implementation of FTIs, CTIs, ATPS, POTPs, and OTPs; detailed test schedule development and implementation; coordination of testing problem resolution; and coordination of testing support activities. Additionally, the TFRSO Startup Manager has the responsibility to support the project as follows:

- Witness factory tests \& inspections, construction tests \& inspections, acceptance testing, pre-operational testing, and operational testing, as deemed necessary.

- Approve construction test and inspection requirements per CWP, FTIs, and POTPS.

- Review and approve FTI specifications, FTI report, ATPs, construction test \& inspection reports, ATRs, POTP reports, and OTRs.

- Review and comment on the Design Agent's system operating descriptions, to be used in the development of test procedures. 
- Prepare initial definition of Safe Work boundaries (which will be included in the test documents).

- Manage planning, scheduling, and work force allocation, for the startup activities.

- Prepare procedures/Training Matrix and Schedule, and Training Plan, to ensure Operation personnel are trained, and qualified to operate and test the system, structures, and components safely.

- Prepare and submit Project documentation generated in support of Validation and Verification (V\&V) activities.

- Prepare for Operations and Maintenance organization, operations and maintenance (i.e., calibration, preventive, corrective....etc.) procedures.

- Include applicable elements of the project safety basis and reguiatory documentation into operator training, operating, maintenance (i.e., calibration, preventive, corrective....etc.), and test procedures.

- Prepare operating surveillance procedures and assure that they incorporate a 11 applicable technical safety requirements.

- Ensure maintenance of testing acceptance records through completion and turnover of the project.

- Document and Prepare Turnover documentation to the facility owner as part of the ABU process. Develop an electronic format for real-time retrieval of turnover material.

- Provide training plans for Tank Farm maintenance and operator training.

- Prepare POTPs, OTPS, and the associated Test Reports generated from completed tests (i.e., FTIS, CTIs, ATPS). [The preparation of the POTPS and OTPS is the overali responsibility of LMHC Tank Farm Operations organization. Tank Farm Operations has contracted with the TFRSO Startup Group to create the POTPs and OTPs.]

- Provide support to Tank Farm Operations scheduling and integration activities for T\&E activities.

- Develop inventory control (e.g., spare parts, storage, special shipping) to ensure spare parts are available for construction and testing.

- Prepare and maintain TEP.

- Prepare STEPS.

\subsection{JOINT TEST REVIEW GROUP (LMHC)}

The JTRG will consist of the Chief Test Director (from the LMHC Test and Startup Organization), Engineering manager (of the facility that will operate the equipment), the Design Authority, applicable Test Director for each ATP, POTP, and OTP, and W-314 TFRSO Startup Manager. The JTRG provides Tank Farm operations with a high level of confidence that the test can be done safely and 
efficiently. The review by the JTRG provides a basis (reference HNF-IP-0842)

for test release. The JTRG conducts thorough reviews of ATPs to ensure compliance with applicable procedural requirements, to ensure they can be done safely, and to ensure the scope of testing and inspections provide a product that satisfies operational and safety requirements. The JTRG reviews test procedure data, and provides their recommendation concerning the final acceptance that test results satisfy the design specifications as stated in the acceptance test procedures or test plans.

\subsection{TEST SUPPORT GROUP (FDNW)}

The Testing and Evaluation process requires effective support from other TFRSO project participants in order to succeed properly. This includes participants that provide Equipment and Material Support, Construction Management, Construction Craft Support, Vendor Services Support, Procedure Development Support, and Startup Services Support including Quality Assurance, Safety, and Environmental Support. The Startup Manager wi1l negotiate and establish working arrangements with each respective participant to ensure that support services (essential for successful and timely testing and evaluation) for the TFRSO Project are provided. Construction Forces/Construction Management (FDNW) wi11 provide the craft and supervision to support testing, including mock-up, through the ATPS, and into the POTPS/OTPS, if required. Additionally, Construction Management will perform the following:

- Review design verification report(s), factory acceptance test specifications, procurement specifications, construction specifications, ATPs, FTI Reports, ATRs, and system turnover.

- Contribute input for construction completion report and 0TPs.

- Review and approve CWPs to insure that required CTIs have been included.

- Prepare CTIs and construction completion report.

\subsection{TANK FARM OPERATIONS (LMHC)}

Tank Farm Operations will provide input and participation in technical reviews of Factory Acceptance Testing, Construction T\&I, acceptance testing, Calibration, Grooming and Alignment, Pre-Operational Testing, and Operational Testing. Additionally, Tank Farms Operations will provide a Test Director and maintenance and operations support during the Pre-operational and operational phase of the Project for equipment and systems that are in TFRSO Project's custody. Specific areas of responsibility include the foljowing:

- Assign an Operations representative to the JTRG (preferably the Operations Test Director for the TFRSO Project). Also, select a lead (selected by the Operations Manager) that will assign members to the management self assessment team, if convened.

- Provide an Operations Engineer to the project to review, validate, document, and act as an Operations Test Director for POTPs and OTPS.

- Review and approve Technical and Operating Specifications (e.g., procurement, construction, and FTIs); ATPs; and Design Verification Reports. 
- Review and approve operating procedures, maintenance (i.e., calibration, preventive, corrective...etc.) procedures, FTI Reports, ATRs, POTP Reports, and OTRs.

- Observe FTIs, acceptance testing, pre-operational testing, and operationa1 testing, as required.

- Witness system turnovers.

- Approve construction completion reports, operator training, and startup and operations testing documentation.

- Participate in the preparation and review of POTPs and OTPs. [The preparation of the POTPS and OTPS is the overall responsibility of LMHC Tank Farm Operations organization. Tank Farm Operations has contracted with the TFRSO Startup Group to create the POTPS and 0TPS.]

- Assist in the validation of OTPs.

- Establishing scheduling, coordinate work release with Startup, package review, and facility protocol guidance for all test activities.

- Support testing scheduling priorities.

\subsubsection{CHIEF TEST DIRECTOR}

The Chief Test Director will participate in the review of acceptance testing documentation as chair of the JTRG, and provide technical overview and decision support as necessary. Included with the responsibilities mentioned above are the following:

- Review selected ATPs, ATRs, POTPs, OTPs, POTP Reports, and OTRs.

- Observe selected FTIs, CTIs, acceptance testing, pre-operational testing, and operational testing.

\subsection{MAINTENANCE GROUP (LMHC)}

The Maintenance Group will provide input and participation in technical reviews of FTIs, CTIs, pre-operational tests, and calibration, grooming and alignment activities. Maintenance will provide support during the pre-operational phase of the Project for equipment and systems that are in the TFRSO Project's custody. Specific areas of responsibility include the following:

- Participate in the preparation and review of Technical and Operating Specifications.

- Review and approve maintenance (i.e., calibration, preventive, corrective...etc.) procedures.

- Participate in the preparation and review of test procedures when requested by the W-314 Project Manager. 
- Train and qualify maintenance personnel in accordance with the Tank Farm's TIM so that maintenance personnel are qualified to participate in testing activities.

\subsection{DESIGN AGENT (FDNW)}

The Design Agent support for T\&E activities will include providing design documents to initiate procedure development, participation on the JTRG, resolution of deficiency punchlist items, and concurring with test

results/reports. Specific Design Agent related responsibilities may include the following:

- Prepare ATPS.

- Prepare Requirements Verification Report(s), FTI specifications, and procurement specifications.

- Concur with Requirements Verification Report(s), FTI specifications, procurement specifications, construction specifications, ATPs, factory acceptance testing, FTI Reports, CTIs, acceptance testing, and ATRs.

- Witness factory acceptance testing, CTIs, and acceptance testing.

- Review CTIs.

- Provide Construction Specifications that define test requirements for SSCS, including acceptance criteria, that can be used to verify that design requirements and construction installation requirements are met.

- Prepare design change requests originating as a result of T\&E activities.

- Prepare system operating characteristics and descriptions to be used by Startup and Operations in development of SSC Startup and Operating Procedures, if required.

- Contribute input for the OTPS and operator training.

- Maintain design configuration control and records through completion of construction acceptance testing in accordance with HNF-PRO-440, "Engineering Documents Change Control Requirements"; HNF-PRO-242, "Engineering Drawing Requirements"; and HNF-IP-0842, "TWRS Administration", VOL. II, section 4.8.3.

\subsection{CONSTRUCTION (FDNW)}

The Construction group for the $W-314$ project wilt perform all construction activities asssociated with the project including construction management, procurements, managing craft personnel, construction quality assurance \& quality control, safety, survey, field engineering, and construction document control. Examples of Construction responsibilities relating to startup activities include the following:

- Review procurement and construction specifications.

- Review ATPS. 
- Witness FTIs, as required.

- Review FTI Reports.

- Construct per the Design.

- Perform CTIs.

- Prepare and maintain CWPS.

- Perform acceptance testing

- Perform Field verification and Closeout.

- Review systems turnover documentation.

- Field verify project drawings as required.

- Support POTPs and OTPS as required.

- Prepare and maintain project construction punchlist.

- Procure construction equipment and materials.

- Perform preventive maintenance as required and maintain in-storage equipment records.

- Perform Quality Assurance oversight of construction and fabrication activities; CTIs; procurement, shipping, receiving, and storage of safety class \& safety significant materials and equipment; control and maintenance of quality records; and Quality Assurance review and approval of CWPs and personnel qualifications/records.

\subsection{MATRIXED ORGANIZATIONS}

Additional support and expertise will be required and is available from a variety of other organizations. It shall be the responsibility of these various organizations to provide input and to participate in the T\&E activities as requested by the TFRSO Project Manager. Some of the Matrixed Organizations that have been identified, along with responsibilities, are as follows:

1) Design Authority (LMHC) - Provide technical overview and approval of T\&E activities/documents and serve as a member of the JTRG. Included with the responsibilities mentioned above are the following:

- Review Design Verification Reports, FTI specifications, procurement specifications, construction specifications, ATPs, CTIs, FTI Report, ATRs, and OTRs.

- Approve Design Verification Reports, FTI specifications, procurement specifications, construction specifications, FTIs, ATPs, FTI Report, ATRs, system turnover, construction completion report, care and maintenance instructions, POTPS, POTP Reports, and startup and operations documentation. 
2) TWRS Training (LMHC) - which will provide Operator and Maintenance training, the Training Plan, and the Certification Package upgrades required to perform POTPS and OTPS;

3) Facility Cognizant Engineer (LMHC)- Wi11 review and approve JCS work control documents and ECNs. Included with the responsibilities mentioned above are the following:

- Review Design Verification Reports, FTI specifications, procurement specifications, construction specifications, ATPS, CTIs, FTI Report, ATRs, and OTRs.

- Approve Design Verification Reports, FTI specifications, procurement specifications, construction specifications, FTIs, ATPs, CTIs, FTI Report, ATRs, system turnover, construction completion report, care and maintenance instructions, POTPS, POTP Reports, and startup and operations documentation.

- Witness selected construction test and inspection, acceptance testing, pre-operational testing, and operational testing.

4) Quality Assurance Services (FDH) - Provides the independent $3^{\text {rd }}$ party (AI) for the project. AI performs the foliowing:

- Approve and systems turnover.

- If required, provide approval for factory acceptance testing, FTI Report, CTI, acceptance testing, ATRs, pre-operational testing, POTP Reports, operational testing, and OTRs.

\subsection{QUALIFICATION AND TRAINING}

For entrance into the Tank Farms, Startup Test Engineers, Operations personne1, Project Team, and related support personnel will be selected and trained in accordance with the requirements of the TIM for Tank Farms which implements the requirements of DOE Order 5480.20A, "Personnel Selection, Qual ification, Training and Staffing Requirements," at DOE Reactor and Non-Reactor Nuclear Facilities. The Test Director conducting the ATPs will be assigned by the Design Agent. Technical proficiency and/or requirements of the ATP Test Director will be determined by the Design Agent. The Test Director that will be conducting the POTPS and OTPS will be a qualified in accordance with the Tank Farm qualifications for a PIC, Operating Engineer, and/or Shift Manager. 
HNF-SD-W314-TEP-001, Rev. 1

Table 3-1 RESPONSIBILITY ASSIGNMENT MATRIX

\begin{tabular}{|c|c|c|c|c|c|c|c|}
\hline Activity, task, product, description & Design Agent & $\begin{array}{l}\text { Construction } \\
\text { Management }\end{array}$ & $\begin{array}{l}\text { Design Authority } \\
\text { IFacinity Cog. } \\
\text { Engineer }\end{array}$ & $\begin{array}{l}\text { W-314 Project } \\
\text { Management \& Engincering } \\
\text { 1) Project Manager } \\
\text { 2) Lead Project Engineer } \\
\text { 3) Lead Test Engineer } \\
\text { 4) Quaity Assurance }\end{array}$ & Tank Farm Operations: & $\begin{array}{l}\text { Chief Test } \\
\text { Director }\end{array}$ & $\begin{array}{c}\text { Quality Assurance } \\
\text { Services } \\
\text { (Al) }\end{array}$ \\
\hline \multicolumn{8}{|l|}{$\mathrm{Dethn}$} \\
\hline $\begin{array}{l}\text { Requirements Vexification Report } \\
\text { (Anahysis, Examination, Demonstration, } \\
\text { \& Test) }\end{array}$ & Prepare, Concur & - & Review, Approve & Review, Approve (1.284) & Review, Approve & - & - \\
\hline Factory acceptance test specification & Prepare, Concer & - & Review, & Reviow, Approve $(2,3 \& 4)$ & Review, Approve & - & - \\
\hline Procurement Specification & Prepare, Concur & Review & Review, & Review, Approve $(1,284)$ & Review, Approve & - & - \\
\hline Construction Specification & Prepare, Concur & Review & Review, Approve & Review, Approve $(1,284)$ & Review, Approve & - & - \\
\hline Acceptance Test Procedures & $\begin{array}{l}\text { Prepare, Concur. } \\
\text { Review } \\
\end{array}$ & Review & Review, Approve & Review, Approve $(1,2,324)$ & Review, Approve & Review & - \\
\hline \multicolumn{8}{|l|}{ Conotucton } \\
\hline Factory Test \& Inspection Procedures & Review, Approve & - & - & Approve $(1,2,384)$ & Approve & - & - \\
\hline Factory Tests \& inspections & Writness, Concur & Witness & - & Withess (3\&4) & Wrincess & $\begin{array}{l}\text { Wituess } \\
\text { (selected tests) }\end{array}$ & As Required \\
\hline Factory Test \& Inspection Report & Prepare, Concur & Review & Review. & Review, Approve (384) & Review, Approve & - & As Required \\
\hline $\begin{array}{l}\text { Construction test \& mspection } \\
\text { requirements per CWP }\end{array}$ & Prepan, Concur & Review & Approve & Approve $(1,2,384)$ & Approve & - & As Required \\
\hline $\begin{array}{l}\text { Construction Test \& knspection } \\
\text { Procodures }\end{array}$ & Peview & Prepare, Approve & Review & Review (3ะ4) & Review & - & Approve \\
\hline Construction acoeptance testing & Witness, Concur & - & Wituess & Witness (3\&4) & Wituess & $\begin{array}{c}\text { Wimess } \\
\text { (selected tests) }\end{array}$ & As Requined \\
\hline Acceptance Testing & Witness, Approve & - & Witness & Witness (384) & Witiness & $\begin{array}{c}\text { Witness } \\
\text { (selected tests) }\end{array}$ & As Required \\
\hline
\end{tabular}

Note that the above table is an example - actual review, approval, and witness responsibilities will be provided in each STEP. Environmental Compliance and Safety \& Health will observe, review, and/or approve the items in the activity, task, product, description column, as required.

Table 3-1 RESPONSIBILITY ASSIGNMENT MATRIX (cont.) 
HNF-SD-W314-TEP-001, Rev, 1

\begin{tabular}{|c|c|c|c|c|c|c|c|}
\hline Activity, task, product, description & Design Agent & $\begin{array}{l}\text { Construction } \\
\text { Management }\end{array}$ & $\begin{array}{l}\text { Design Authority/ } \\
\text { Facifity Cog. } \\
\text { Engineer }\end{array}$ & $\begin{array}{l}\text { W-314 Profect } \\
\text { Management \& Engiveering } \\
\text { 1) Project Manager } \\
\text { 2) Lead Project Engineer } \\
\text { 3) Lead Test Engineer } \\
\text { 4) Ouality Assuranco }\end{array}$ & Tank Fam Operations & $\begin{array}{l}\text { Chief Test } \\
\text { Director }\end{array}$ & $\begin{array}{c}\text { Quality Assurance } \\
\text { Service } \\
\text { (AD) }\end{array}$ \\
\hline Acceptance Jest Report & Prepare, Conetr & $=$ & Review & Review (4), Approve (4) & Review, Approve & Review & As Requined \\
\hline Systems thmover & $=$ & $=$ & Review a Approve & Prepare (3) & Approme & - & Approve. \\
\hline Construction completion report & $=$ & Prepare & Approve & Peview $(1,2,384)$ & Approve & - & $=$ \\
\hline \multicolumn{8}{|l|}{ stantopd operations } \\
\hline STIEP Preparation & Review, Approve & Reviow, Approve & Pleview, Approve & $\begin{array}{c}\text { Review, Approve }(1,2,3, \\
84]\end{array}$ & Review, Approve & $\begin{array}{l}\text { Review, } \\
\text { Approve }\end{array}$ & - \\
\hline Cane and maütenance instructions & =- & - & Approwe & Prepare, Review (283) & $=$ & $=$ & - \\
\hline - Pre-operational Test Procedures & Roviow & - & Approve & - & Prepare, Approve & Review & - \\
\hline Pre-operctional testing & - & - & - & Witness $(3 k 4)$ & Writuess & Writiess & As Required \\
\hline Pre-operational Test Reports & - & - & Approve & $\begin{array}{l}\text { Prepare (3), Review, } \\
\text { Approve }(1,2,3 \& 4)\end{array}$ & Approve & Review & As Requined \\
\hline - Operational Jest Procedures & - & - & Approve & - & Prepare, Approve & Review & - \\
\hline Operational testing & - & - & - & Witness (384) & Withess & Witness & As Plequined \\
\hline Operational Test Reports & - & - & Rovion, Approve & $\begin{array}{l}\text { Prepare (3), Review, } \\
\text { Approve }(1,2,384)\end{array}$ & Review, Approve & Review & As Requined \\
\hline Operator trining & Contributes input & - & - & Prepare (3) & Approve & - & - \\
\hline Startup and operations documentation & - & - & Approve & Prepare (3) & Approve & - & - \\
\hline
\end{tabular}

* Actual Function Performed by NHC Startup organization.

Note that the above table is an example - actual review, approval, and witness responsibilities will be provided in each STEP. Environmental Compliance and Safety \& Health will observe, review, and/or approve the items in the activity, task, product, description column, as required. 
HNF-SD-W314-TEP-001, Rev. I

\section{CHAPTER 4}

\section{PROJECT W-314 STRATEGY AND APPROACH}

The primary goal of the W-314 Strategy and Approach is to ensure that T\&E activities have sound technical, cost and schedule basis, and that a formal system is in place to authorize and control the T\&E activities. This section describes how the $W-314$ Project will establish, manage, and control testing work scope, cost, scheduling, measurement, and work performance. In addition, this section discusses plans for management of test records and compilation of historical data for Lessons Learned benefit.

\subsection{T\&E ADMINISTRATIVE ACTIVITIES}

This section details and explains the overall Administrative tasks for T\&E activities. Testing and Evaluation activities must be managed in a manner to ensure that they are performed to a high degree of quality. This includes activities to provide proper levels of appropriately trained and experienced staff, develop quality test procedures, conduct technical reviews, ensure quality test documentation and records management, and adequate evaluation/actions to maintain the T\&E performance at quality levels.

T\&E planning and support, testing, and turnover schedules will be fully resource loaded to permit identification of all necessary personnel required to support the T\&E program.

In order to ensure quality test procedure preparation, all POTPs and 0TPs shall be prepared in accordance to HNF-IP-0842, Vol 1 (sec 2.11) and HNF-IP-0731 (Writer's Guide). All other tests will be prepared in accordance with HNF-PRO-446, "TESTING PRACTICES REQUIREMENTS". Test reviewS will be conducted before, during, and after testing, as required, to ensure the test encompasses all applicable requirements and validate test results

Test procedures will be developed, approved, and maintained in accordance with HNF-PRO-229, "TECHNICAL PROCEDURE STANDARD". Project test procedures will be controlled by HNF-PRO-439, "SUPPORTING DOCUMENT REQUIREMENTS". Test specifications, test procedures, and test reports shall be controlied, approved, and released by approved administrative procedures, (see Appendix A).

\subsection{T\&E WORK CONTROLS}

This section communicates all activities necessary to manage and control T\&E scope of work. T\&E activities must be planned, controlled, scheduled, and managed in an effective manner to ensure that all work is performed to a high degree of quality, efficiency, and cost effectiveness. This TEP includes activities that develop and implement processes and procedures to ensure effective planning, scheduling, work control, and management of the overall testing program. Also, T\&E activities work scope will be established and controlled in accordance with the TFRSO TEP and the TFRSO STEPS

The first component of effective Work Management is thorough and detailed planning. The planning phase of the TFRSO T\&E program includes the following activities: 
1. Identification of SSC testing requirements as defined in the design documentation.

2. Integration of the T\&E schedule data to the TFRSO Project Schedule and refinement, as required.

3. STEPs map out logical and sequential testing activities. STEPs will be sequenced and scheduled to minimize use of temporary equipment and to maximize the use of in-place tested equipment. Test sequencing should also be utilized to minimize operational impacts and downtime of critical SSCs. Detailed testing sequence logic diagrams, will be developed, based on knowledge of system scoping boundaries, system testing requirements, the testing activity interfaces, or other non-testing project activities, such as construction turnover and readiness review processes. SSC testing requirements will be extracted from all applicable documents related to the TFRSO project such as PDS, definitive design drawings (including A-E generated test specifications), construction specifications, and identified DOE Orders.

4. Refinement of system scoping boundaries to accurately define testable packages of equipment and systems.

The second component of effective Work Management is scheduling of T\&E activities. A1T activities addressed in the TEP and/or STEPs will be scheduled and fully integrated with the project construction schedules and Tank Farm Integrated Schedule. Particular emphasis shall be placed on those activities necessary to support any Project System Readiness Activities and the Start of Initial Operations.

A Startup Schedule Baseline will be developed and maintained for the TFRSO Project office. The T\&E schedule includes two integrated but distinct schedules:

1. T\&E TURNOVER AND TESTING SCHEDULE - This schedule maps out all support work for the T\&E program. This includes planning and support activities by organizations such as the Startup group, PHMC Matrixed organizations, the Design Agent, construction contractors, vendors, and other TFRSO participants. This schedule is integrated with the TFRSO Project and/or Construction Schedule to assure that all activities are budgeted for.

2. SPECIFIC TEST \& EVALUATION PLAN SCHEDULE - This schedule is a detailed sequence of activities that establishes SSC turnover dates to assure that the project deliverables meet their functional requirements.

\subsection{PROJECT MANAGEMENT AND ENGINEERING}

This section is provided because it develops in greater detail T\&E activities that will be performed by TFRSO Startup Group. These activities must be executed in an effective manner to ensure a safe, technically competent, and expeditious startup of the TFRSO SSCS. This section spans the following activities:

- Review of appropriate Test Procedures provided by the A-E.

- Implementation of specific testing method(s) identified in the STEP. 
- Rigorous adherence to testing controls identified in the STEP.

- Development of test sequences and schedules that allow testing to proceed in logical steps that build on each others foundations.

- Preparation and issuance of test procedures in a controlled and timely manner.

- Identification and control of test equipment, instrumentation, and other materials required to support testing activities to assure appropriate and accurate data collection.

- Test performance that is conducted by appropriately trained and experienced personnel.

- Post-test reviews and analysis of test results by TFRSO JTRG to verify acceptability of the tested SSC.

- Participate in construction turnover walkdowns, oversee AI punchlist resolutions, preparing and executing pre-operational test procedures, supporting systems readiness for initial hot operations, and supporting the TFRSO Project during initial hot operations.

- Proper documentation of test results and documentation reviews conducted to verify acceptability of the test results.

- Transmittal of documentation associated with testing programs to project files and Information Resource Management for storage in a PHMC records storage facility in accordance with HNF-CM-3-5, "Document Control and Records Management.

\subsection{FILING AND RECORDS MANAGEMENT}

This activity includes a11 work activities required to establish and maintain the T\&E file system, all T\&E records management systems, and Lessons Learned records. The filing and records management system for Startup will be structured to maintain on-line retrievable Project records. T\&E Documents wi11 be maintained and retrievable on a real-time basis. 


\section{REFERENCES}

DOE Order 5480.19, Conduct of Operations Requirements for DOE Facilities, U.S. Department of Energy, Washington, D.C.

DOE Order 5480.20A, Personnel Selection, Qualification, Training, and Staffing Requirements at DOE Reactor and Non-Reactor Nuclear Facilities, U.S. Department of Energy, Washington, D.C.

DOE Order 55480.31, Startup and Restart of Nuclear Facilities, (DOE 1993), U.S. Department of Energy, Washington, D.C.

DOE Order 4700.1, 1987, Project Management System, U.S. Department of Energy, Washington, D.C.

DOE Order 430.1, Life Cycle Asset Management, U.S. Department of Energy, Washington, D.C.

HNF-PR0-081, Hazardous Energy Control Program, Fluor Daniel Hanford Company, Richland, Washington.

HNF-PR0-229, Technical Procedure Standard, Fluor Daniel Hanford Company, Richland, Washington.

HNF-PR0-439, Supporting Documents Requirements, Fluor Daniel Hanford Company, Richland, Washington.

HNF-PRO-242, Rev. 1, Engineering Drawing Requirements, Fluor Daniel Hanford Company, Richland, Washington.

HNF-PR0-440, Engineering Document Change Control Requirements, Fluor Danie1 Hanford Company, Richland, Washington.

HNF-PR0-446, Testing Practices Requirements, Fluor Daniel Hanford Company, Richland, Washington.

HNF-PR0-551, Statement of Work for an Offsite $A-E$, Fluor Daniel Hanford Company, Richl and, Washington.

HNF-PRO-572, Project Acceptance and Closeout, Fluor Daniel Hanford Company, Richland, Washington.

HNF-PRO-574, Project P7an, Fluor Daniel Hanford Company, Richland, Washington.

HNF-CM-1-5, Standard Operating Procedures, Fluor Danie1 Hanford Company, Richland, Washington.

HNF-CM-1-6, Radiological Control Manua7, Fluor Daniel Hanford Company, Richland, Washington.

HNF-CM-1-8, Work Management, Fluor Daniel Hanford Company, Richland, Washington. HNF-CM-1-10, Safety Manual, Fluor Daniel Hanford Company, Richland, Washington. 
HNF-CM-2-5, Management Control System, Fluor Daniel Hanford Company, Richland, Washington.

HNF-CM-3-5, Document Contro7 and Records Management, Fluor Daniel Hanford Company, Richland, Washington.

HNF-CM-4-2, Quality Assurance Manua7, Fluor Daniel Hanford Company, Richland, Washington.

HNF-IP-0731, Writer's Guide, Fluor Daniel Hanford Company, Richland, Washington.

HNF-IP-0842, TWRS Administration, Fluor Daniel Hanford Company, Richland, Washington.

HNF-SD-W314-PMP-001, Project Execution P7an, Numatec Hanford Corporation, Richl and, Washington.

HNF-SD-WM-BI0-001, Rev. F, TWRS Basis for Interim Operation, Fluor Danie1 Hanford Corporation, Richland, Washington.

HNF-SD-W314-QAPP-001, Tank Farm Restoration and Safe Operations Quality Assurance Program P7an, Fluor Daniel Hanford Corporation, Richland, Washington. HNF-SD-W314-SSPP-001, The Project System Safety Program P7an, F1uor Danie1 Hanford Corporation, Richland, Washington. 
HNF-SD-W314-TEP-001, Rev . 1

\section{GLOSSARY}

Component - A single piece of equipment (such as a run of pipe, valve, protective device, instrument, wire, heat exchanger, pump, turbine, etc.), which will be used with other components to form a system.

Initial Startup Test - Those tests which require process material or simuiant (water) of process material which are performed prior to completion of Operation Readiness Evaluation by DOE. Initial Startup Tests are designed to confirm the design basis and demonstrate that the facility is capable of operating under normal and abnormal conditions.

Pre-Operational Test - Test performed on systems, normally prior to fuel loading or simulant (water) runs, which may be performed without process material, nuclear fuel, or heat. Tests that demonstrate capability of system(s) to meet operational and safety criteria, verify trips, isolations, alarms and parameter indication through the systems full operating range.

Startup - The process of placing or restarting a facility or major modification in operation. The process may start with the checkout, test, calibration, trial, demonstration, and verification steps on individual components of mechanical and electrical equipment and ends with release for normal operation to Facility Operations by the ABU process.

Subsystem - A group of assemb]ies or components or both combined to perform a single function.

System - A group of components united by some interaction or interdependence but functioning as a single unit.

System Index - A listing of systems which represent the scope of the facility project that are being added new or modified.

Test Procedure - A17 Startup Test Procedures and any Plant Procedures that are being conducted under the Startup Test Program requirements.

Test Specifications - Specifications will establish test requirements and parameters for all Tevels of tests performed on major components, subsystems, or systems as applicable to ensure that essential design, interface, and performance requirements are met.

Test Summary Reports - A comprehensive summary report of Startup test procedure results that provide final approval of test results.

Work Package - A collection of documents used to authorize, document, and provide instruction for the performance of maintenance, testing or modification activity. The work package may include, as applicable, design changes, job scope, retest requirements, parts lists, data sheets, applicable procedures, etc. 
HNF-SD-W314-TEP-001, Rev. 1

\section{APPENDIX A}

\section{T\&E Administrative Procedures Checklist}

The T\&E Administrative Procedures Checklist will be prepared to verify procedures are in $\mathrm{place}$ to control the conduct of the W-314 T\&E Program activities. The checklist will consist of three sections; Custody Controls, Work Controls and Testing Controls. Each section of the checklist will identify the procedures that direct the conduct of $W-314$ testing and evaluation activities. Project specific procedures will only be prepared if existing procedures are not adequate. The three sections are explained as follows:

- CUSTODY CONTROLS - This section consists of procedures that govern the conduct of Startup System Scoping, System Turnover Walkdowns, System Turnover and Acceptance process, master tracking system, turn back to construction, and release to operations activities.

- WORK CONTROLS - This section consists of procedures that govern the conduct of engineering issues management, requests for construction assistance, requests for operations assistance, control of temporary modifications, control of Measuring and Test Equipment (M\&TE), Lock and Tag, Work Management, and Master Tracking System.

- TESTING CONTROLS - This section consists of procedures that govern the conduct of test procedure preparation and approval, test procedure implementation, post testing review and approval, and post maintenance testing.

The following Table A-1 designates all the applicable documents/procedures that correspond to a specific startup activity and; therefore, satisfies the requirements of the checklist. The table has been broken out per the three sections defined above. 
HNF-SD-W314-TEP-001, Rev. 1

Table A-1 T\&E ADMINISTRATIVE PROCEDURE MATRIX FOR TESTING

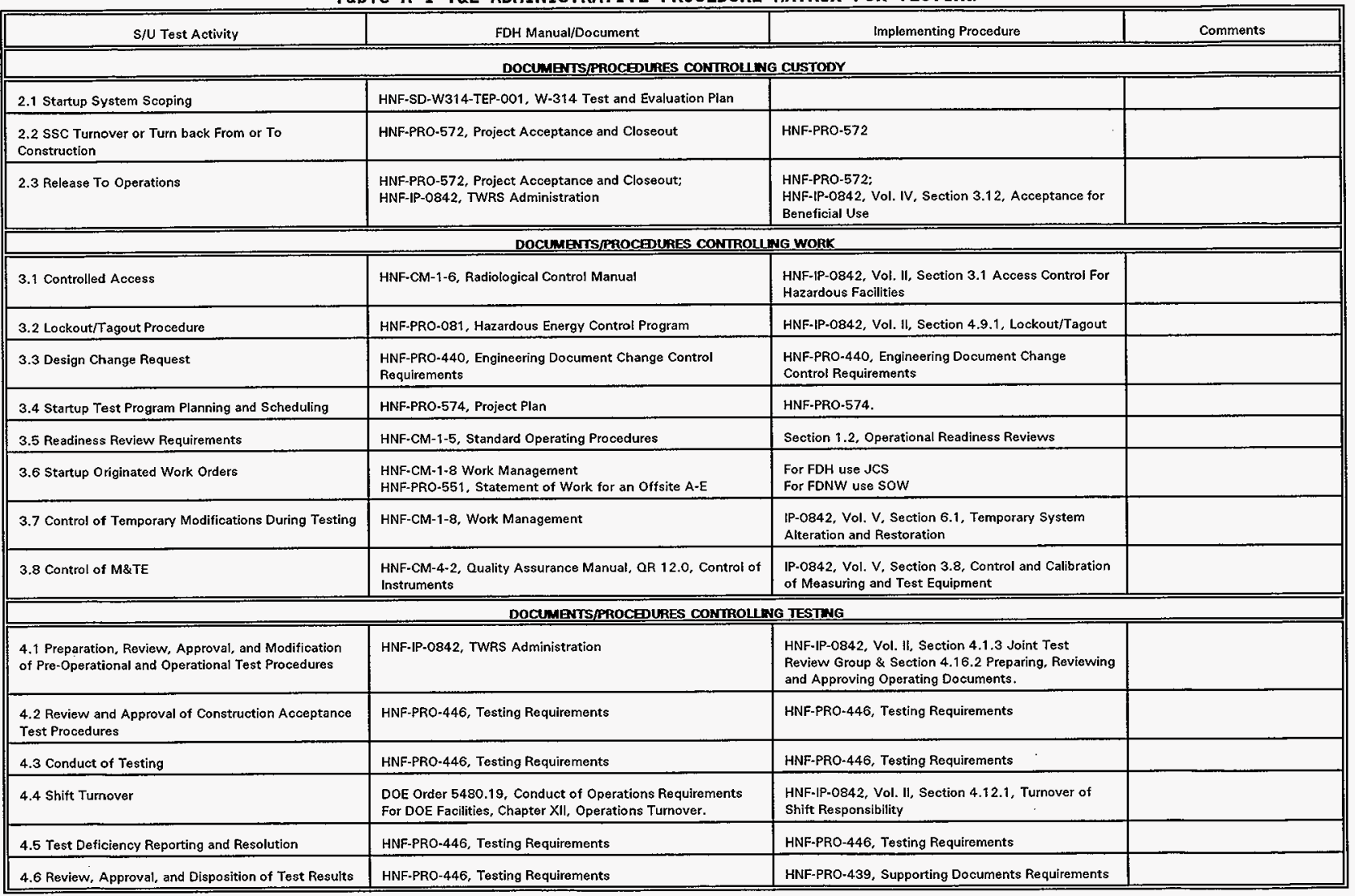


HNF-SD-W314-TEP-001, Rev, 1

\section{APPENDIX B}

TEST AND EVALUATION LOGIC DIAGRAMS AND OVERVIEW DEFINITION DOCUMENT

\section{PURPOSE}

The purpose of the Test and Evaluation Logic Diagram and the Overview Definition Document is to provide a roadmap detailing typical test(s) which verify and validate SSC construction modification. The Test and Evaluation Logic Diagram provides a visual indication of the STEPs and typical tests to complete validation and verification. The Overview Definition Document describes the test shown in the V\&V Logic Diagram in greater detail. What is shown is a typical break down for validation and verification. Included in this appendix will be the STEPs as mentioned in the Overview Definition Document. These STEPS will be further developed at a later time. A listing of STEPs is provided below. Note that STEP fifteen is reserved for a phase two construction item and that STEP document numbers wi11 be added to the TEP when determined.

1) TWR-XXXX, Rev 0, Master Pump Shutdown Upgrade

2) HNF-1733, Rev 1, AN-A Valve Pit Upgrade

3) HNF-1902, Rev 1, AN-B Valve Pit Upgrade

4) TWR-2271, Rev 0, SN-630 Transfer Line (AZ-02A to $A N-B)$

5) TWR-2272, Rev $0, A X-B$ Valve Pit Upgrade

6) TWR-2273, Rev 0, SN-632 Transfer Line ( $A X-B$ to $A Z-02 A)$

7) TWR-XXXX, Rev 0, AZ-02A Pump Pit upgrade

8) TWR-2274, Rev $0, S N-634$ Transfer Line $(A-B$ to $A X-B)$

9) TWR-2275, Rev $0, A-B$ Valve Pit Upgrade

10) TWR-2611, Rev 0, AY-01A Pump Pit Upgrade

11) TWR-2612, Rev 0, SN-635 Transfer Line ( $A Y-01 A$ to $A Y-02 A$ )

12) TWR-2613, Rev 0, AY-02A Pit Upgrade

13) TWR-XXXX, Rev 0, SN-501A Transfer Line (AZ-02A to AZ-01A)

14) TWR-XXXX, Rev 0, AZ-01A Pit Upgrade

15) TWR-2276, Rev 0, SL-633 Replacement Line

16) TWR-XXXX, Rev 0, AW-A Valve Pit Upgrade

17) TWR-XXXX, Rev $0, A W-B$ Va7ve Pit Upgrade 
HNF-SD-W314-TEP-001, Rev, 1

TABLE B-1 W-314 PHASE I OVERVIEW DEFINITION DOCUMENT

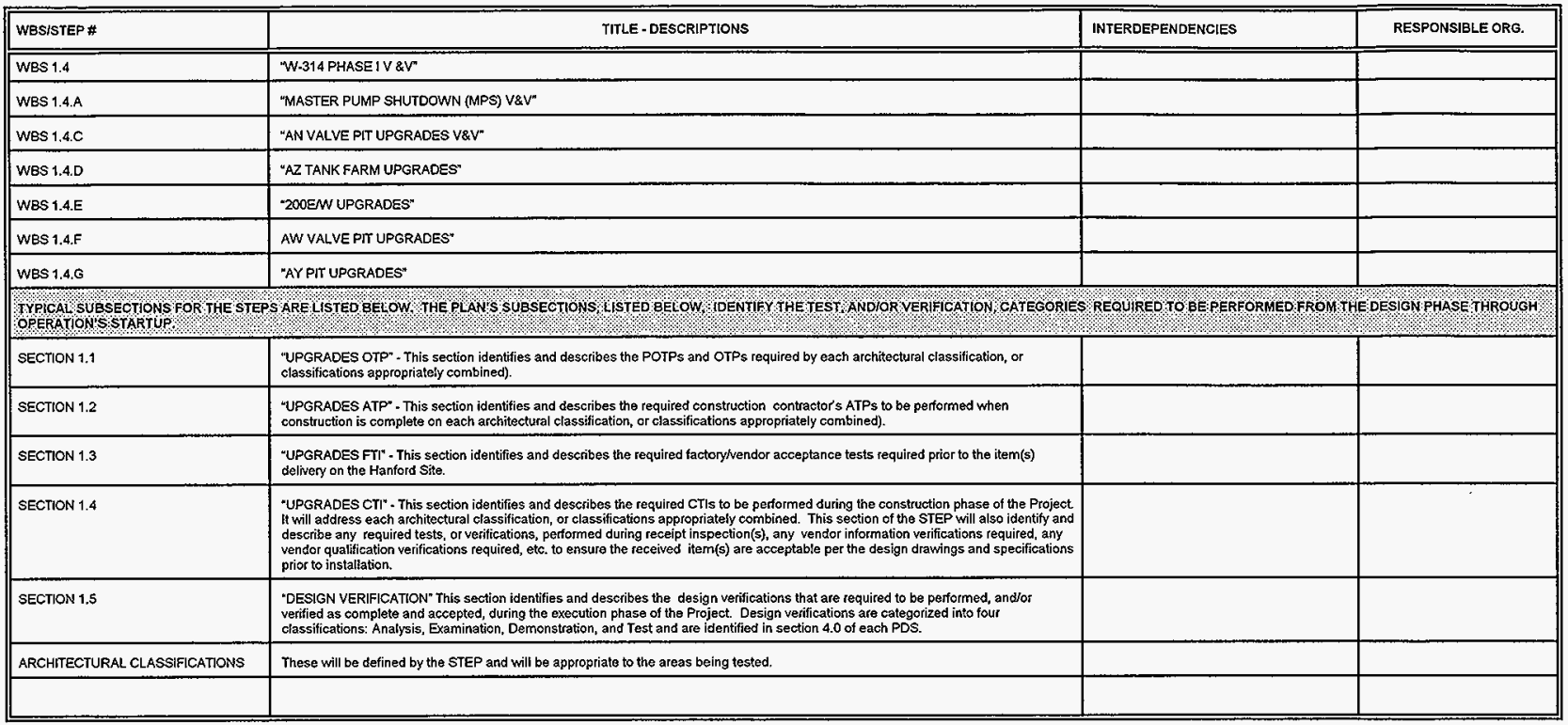


HNF-SD-W314-TEP-001, Rev, 1

FIGURE B-2 TESTING AND EVALUATION LOGIC DIAGRAM

T \& E WBS OVERVIEW, PHASE I

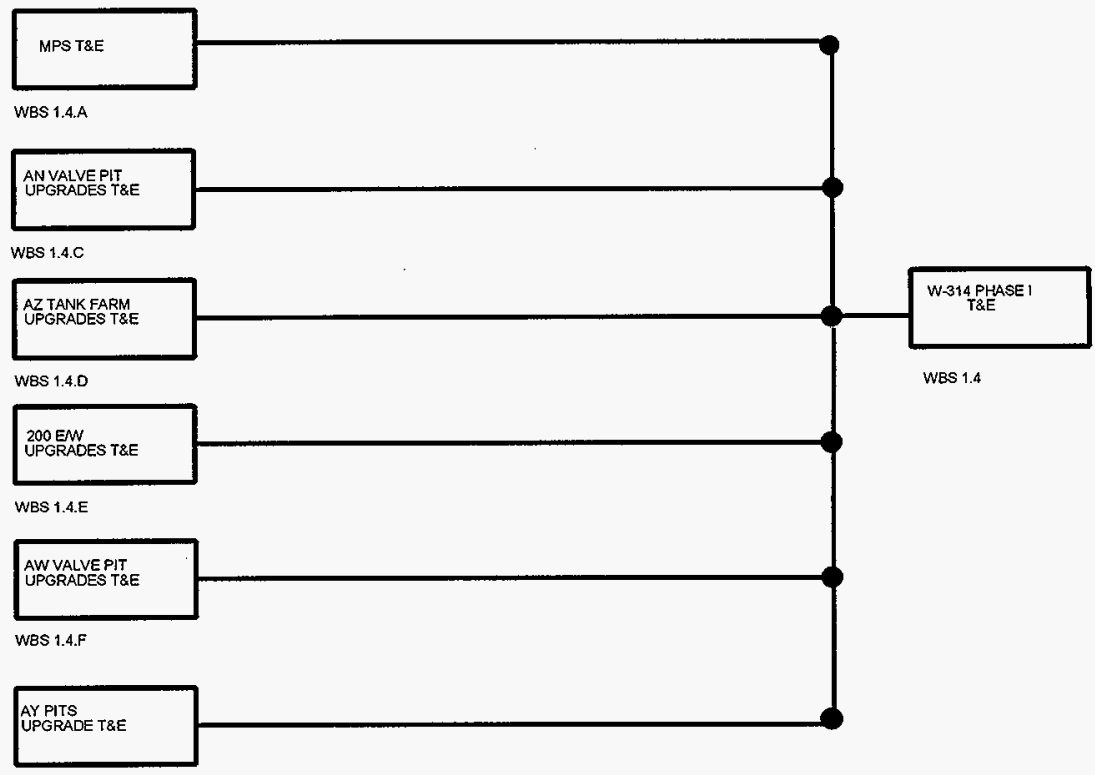

Wes 1.4.G 
HNF-SD-W314-TEP-001, Rev. 1

\section{FIGURE B-3 V\&V LOGIC DIAGRAM FOR AN TANK FARM}

$=$ INTEROEPENDENACIES

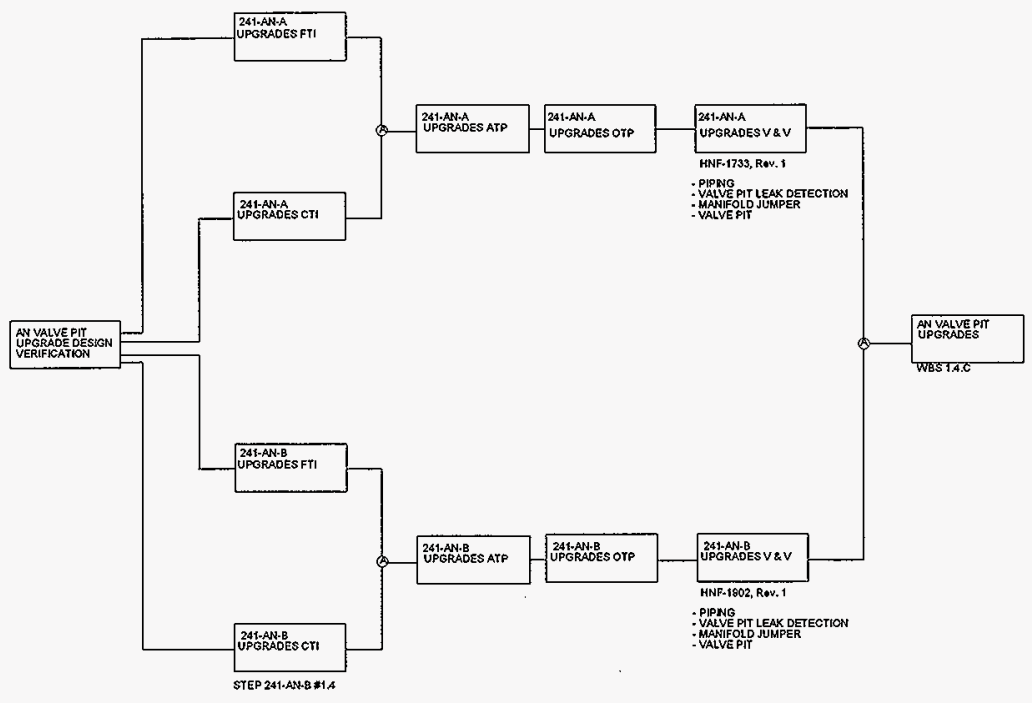




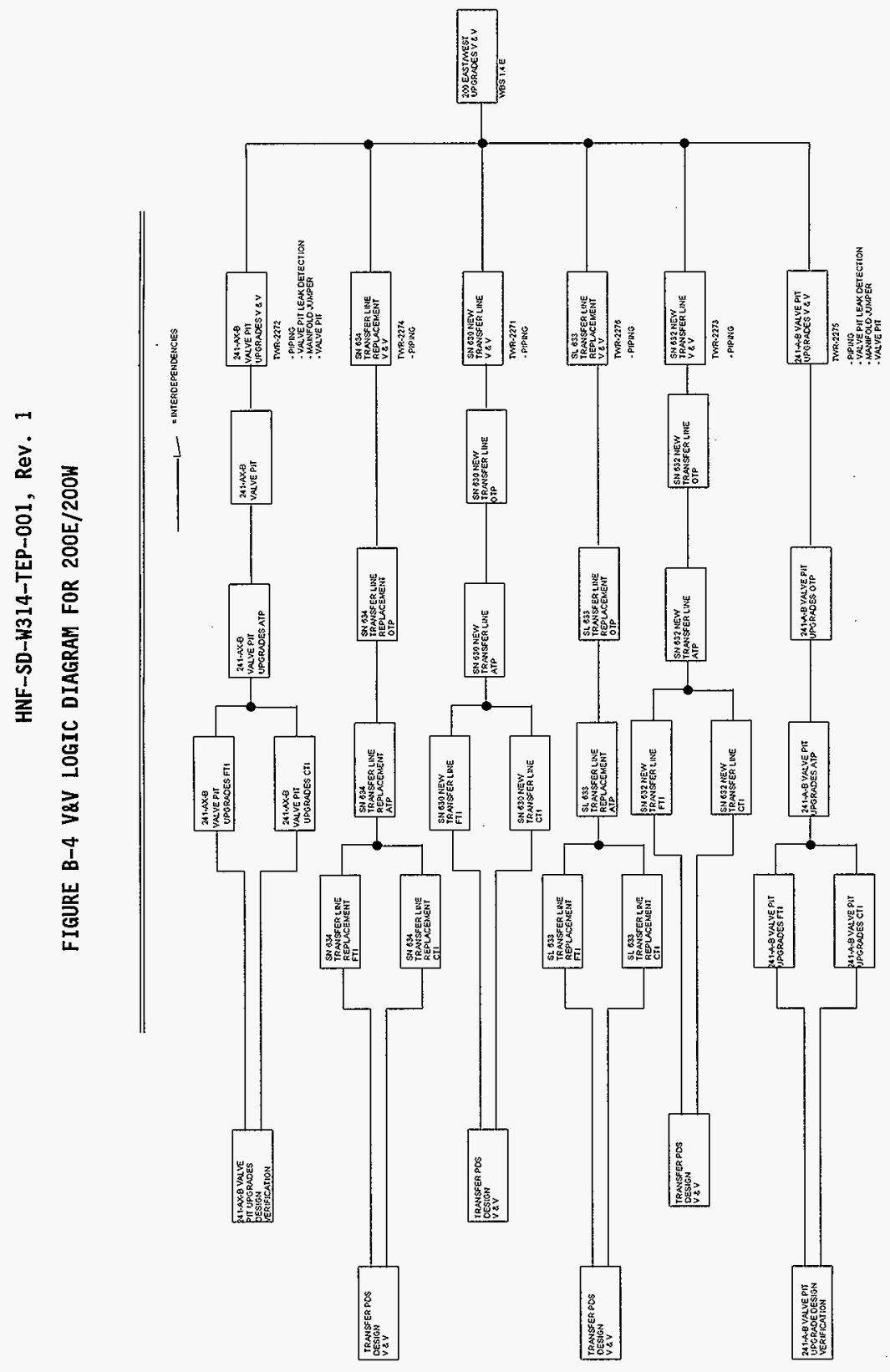

m 
HNF-SD-W314-TEP-001, Rev. 1

FIGURE B-5 V\&V LOGIC DIAGRAM FOR AW TANK FARM

- INTERDEPENDENCIES

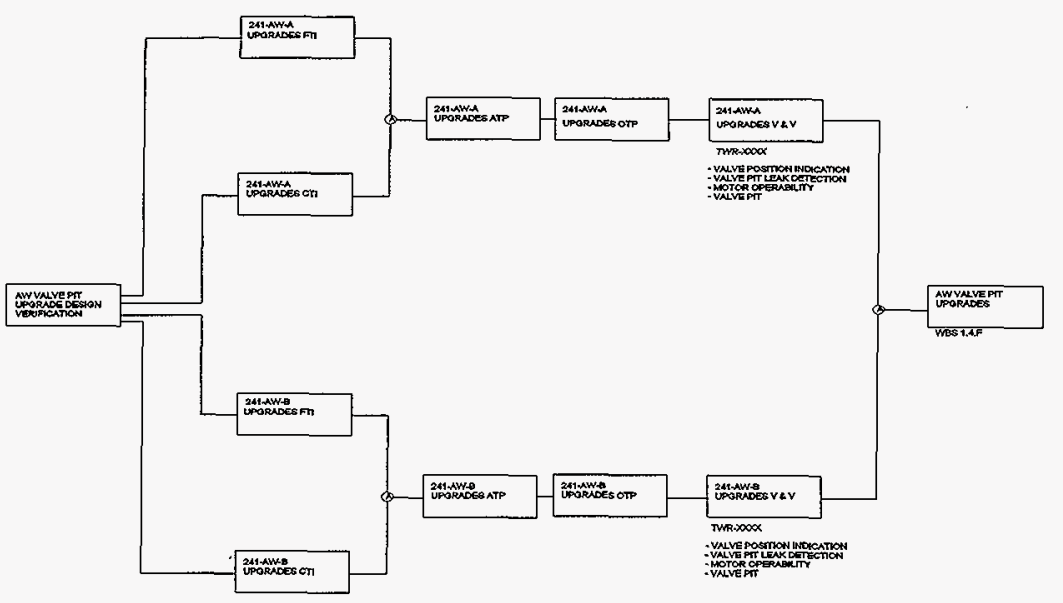


HNF-SD-W314-TEP-001, Rev, 1

\section{FIGURE B-6 V\&V LOGIC DIAGRAM FOR AY TANK FARM}

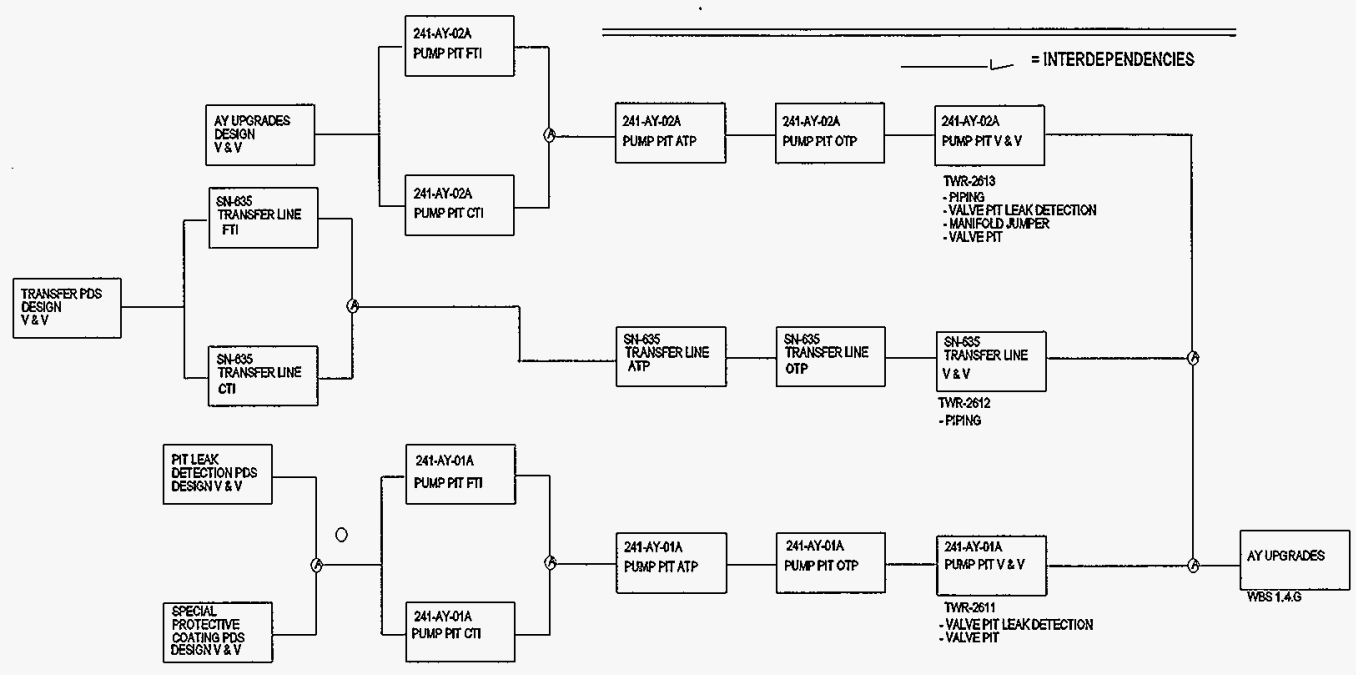


HNF-SD-W314-TEP-001, Rev. 1

FIGURE B-7 V\&V LOGIC DIAGRAM FOR AZ TANK FARM

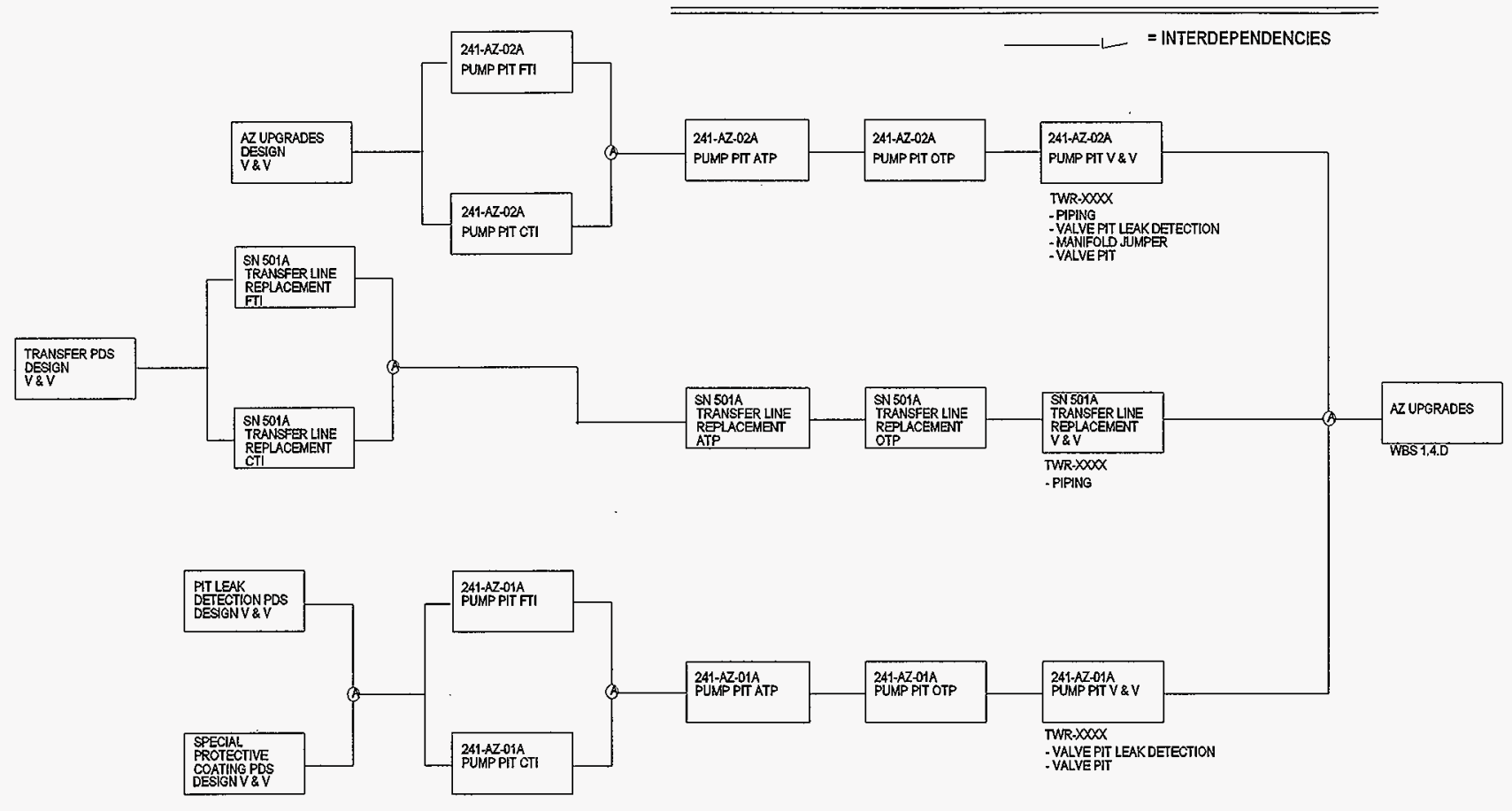


* Information about this logic diagram has yet to be deterained. Logic Diagram will be revised uhen data becomes available.

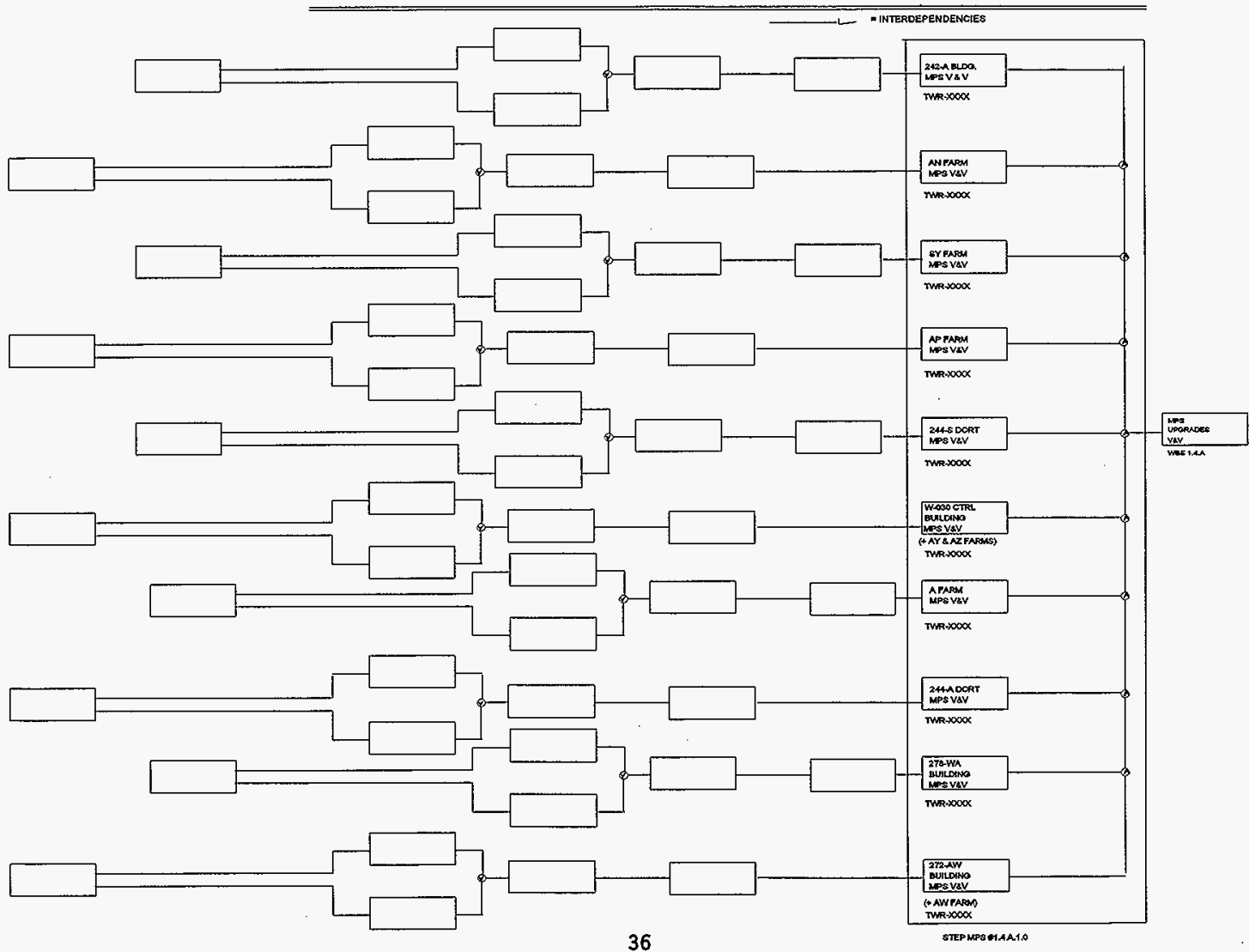




\section{DISTRIBUTION SHEET}

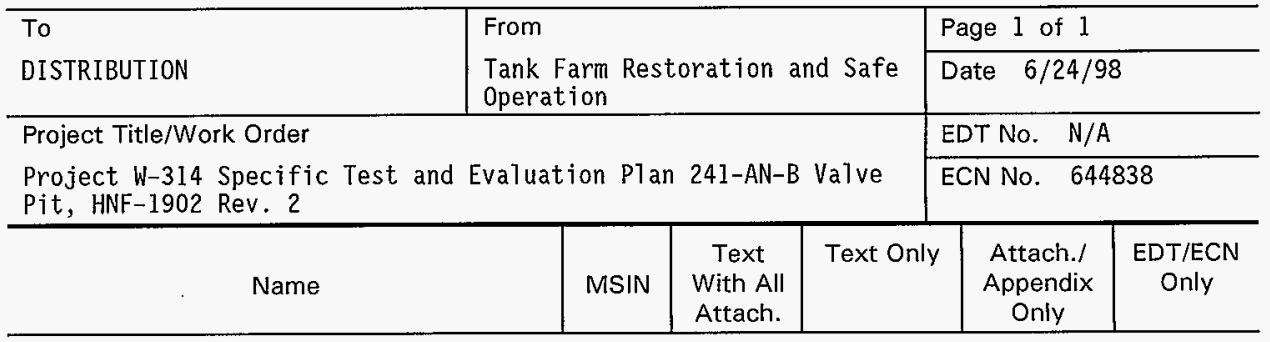

K. A. Boes

D. E. Bowers

R. L. Brown

J. W. Comer

H. M. Chafin

M. P. Delozier

D. P. Devine

D. 0. Dobson

R. A. Dodd

J. D. Galbraith

P. A. Haine

E. A. Harding

C. E. Hatch

W. H. Hays

J. L. Homane

R. W. Jacobson

L. J. Keith

J. T. Koberg

J. R. LaPointe

S. L. Leckband

R. L. Legg

D. L. McGrew

P. C. Miller

D. R. Nunamaker

E. A. Pacquet

T. K. Ravencraft

D. W. Reberger

M. D. Rickenbach

C. A. Rieck

B. L. Syverson

W. T. Thompson

M. W. Tiffany

T. L. Warnick

S. U. Zaman

Project Files (2)
R3-25 $x$

S5-13 $x$

S5-07 $x$

R2-82 $\quad x$

R3-25 $x$

H7-07 $x$

S5-50 $x$

R2-50 $x$

S5-07 $x$

H5-49 $\mathrm{X}$

R3-47 $x$

B4-57 $x$

A3-03 $x$

B4-57 $x$

R2-58 $x$

R2 $-50 \quad x$

R2-84 $x$

G3-12 $X$

R2-88 $x$

R3-47 $x$

R2 $-50 \quad x$

R3-25 $x$

T4-08 $x$

T4-07 $x$

R3-47 $x$

S5-03 $x$

S5-13 $x$

G3-12 $X$

S2-48 $x$

G3-12 $X$

G3-21 $x$

R1-49 $X$

E6-11 $x$

S5-12 $\mathrm{x}$

R1-29 $\mathrm{X}$

\section{Central Files}

B 1 -07 $x$

